\title{
Pampered Bureaucracy, Political Stability, and Trade Integration
}

by

Caleb Stroup and Benjamin Zissimos

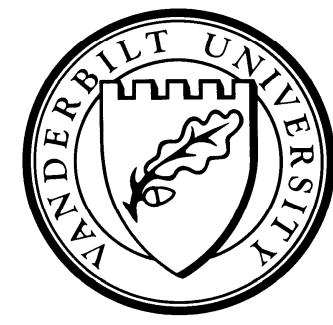

Working Paper No. 11-W05

First draft: April 2010

Revised: June 2011

\section{DEPARTMENT OF ECONOMICS \\ VANDERBILT UNIVERSITY \\ NASHVILLE, TN 37235}

www.vanderbilt.edu/econ 


\title{
Pampered Bureaucracy, Political Stability, and Trade Integration ${ }^{1}$
}

\author{
Caleb Stroup \\ Ben Zissimos ${ }^{2}$ \\ Vanderbilt University
}

First draft: April 29th 2010

This draft: June 4th 2011

\begin{abstract}
This paper shows how, under threat of revolution, a nation's elite are able to maintain political stability and hence ownership of their wealth by creating or expanding a 'pampered bureaucracy.' The elite thus divert part of an otherwise entrepreneurial middle class from more productive manufacturing activities, reducing economic efficiency. If the country has a comparative advantage in primary products, trade integration is potentially destabilizing since it raises the payoff to the lower classes of mounting a revolution and challenging the elite for their wealth. In that case trade integration mandates expansion of the pampered bureaucracy. Therefore, trade integration may actually reduce economic efficiency. The econometric results provide supportive evidence for our model.
\end{abstract}

KEYWORDS. Efficiency, inefficient institutions, property rights, social conflict, trade integration.

Jel Classification Numbers: D30, D74, F10, O12, P14.

\footnotetext{
${ }^{1}$ Previously circulated under the title "Pampered Bureaucracy and Trade Liberalization." For useful comments and/or conversations about earlier versions of the paper we thank Daron Acemoglu, Constantine Angyridis, Klenio Barbosa, Tibor Besedes, Rick Bond, Maggie Chen, Bill Collins, Kerem Cosar, Arnaud Costinot, Mario Crucini, Amrita Dhillon, Bob Driskill, Chris Ellis, James Foster, Bernardo Guimaraes, Oleg Itskhoki, Rod Ludema, Anna Maria Mayda, Ajit Mishra, Dilip Mookherjee, Michael O. Moore, German Pupato, Joel Rodrigue, Rubens Segura-Cayuela, Vladimir Teles, Ping Wang, Quan Wen, Isleide Zissimos, and seminar participants at Essex, FGV (Rio de Janeiro and Sao Paulo), George Washington, Georgetown, Georgia Tech, Ryerson, University of Cyprus, Vanderbilt, the Fourth Southeastern International Development Conference, Atlanta, the Midwest Meetings, Wisconsin, and the Southern Economic Association Meetings, Atlanta. For excellent research assistance, thanks are due to Sarah Brand and Mike Slade. Financial support by the Center for the Americas at Vanderbilt University is also gratefully acknowledged.

${ }^{2}$ Corresponding author: Department of Economics, Vanderbilt University, Nashville, TN 37235.

Tel: ++16153223339 .

E-mail: ben.zissimos@vanderbilt.edu
} 


\section{Introduction}

A salient feature of many developing countries, notably those in Africa, Latin America and the Middle East, is the existence in those countries of an apparently wasteful government bureaucracy. More striking still is that this bureaucracy often has demanding entry criteria, admitting capable applicants predominantly from the middle classes, but then offers its employees highly protected lifetime employment with limited productivity incentives. We will refer to this institution as a 'pampered bureaucracy'. Varma (1998) documents the division within the middle classes created by the states' actions to set up such an institution and its equivalent created by the middle classes' own efforts in the private sector. Thus Varma (1998) makes a useful distinction, which we will exploit, between the conventional role of the entrepreneurial middle classes as key drivers of economic growth and the less familiar role of the middle classes employed in the pampered bureaucracy as a brake on economic development.

The purpose of this paper is to explore the relationship between potential social conflict, trade integration and economic efficiency. Much of the literature in economics, especially in international trade, takes factor ownership as fixed. Yet recent research has established the prevalence in countries with highly skewed income distributions and poor property rights enforcement of land expropriation and politically motivated violence in response to real income shocks. For example, Hidalgo, Naidu, Nichter and Richardson (2010) study a database of over five thousand occurrences of land invasion in Brazil, showing how this type of political violence is provoked by real income shocks associated with rainfall. Their study helps establish the empirical relevance of the type of redistributive conflict on which we will focus. (See also Do and Iyer 2006, Dube and Vargas 2006 and Angrist and Kugler 2008.) A central focus of the present paper is on the implications for economic efficiency of the real income shocks provoked by trade integration when land may be expropriated in the process of a revolution and when the elite can maintain political stability by manipulating the size of the pampered bureaucracy. ${ }^{3}$

Our paper's first main contribution is to show how, in the face of the threat of

\footnotetext{
${ }^{3}$ As standard in the economics literature, revolution has two components: One is economic, whereby the rest of society expropriate the elites' wealth. The second is political, whereby the elite are stripped of their political power and influence which are directed in our setting at employment in the bureaucracy.
} 
revolution, a nation's elite can influence the size of the pampered bureaucracy to maintain the status quo and in doing so limit the emergence of an entrepreneurial middle class. Since employment in manufacturing is more productive than in the pampered bureaucracy, increasing the size of the pampered bureaucracy reduces economic efficiency and in this sense it may be regarded as an inefficient economic institution. Thus we present a new way of understanding how a dictatorship is able to prevent a political transition, or prolong the transition to democracy, benefitting themselves at the expense of national welfare. Since expansion of the pampered bureaucracy implies a contraction of the manufacturing sector, we also present a new way of understanding the natural-resource curse documented by Sachs and Warner (2001) among others, whereby natural-resource-rich countries exhibit relatively slow growth of gross domestic product (GDP) attributed to slow growth in manufacturing.

The prior literature has built on the basic idea that powerful groups within a society manipulate institutions to maintain their power and wealth in the face of challenges from other groups (North 1981). One branch of the literature has focused on the conditions under which civil conflict breaks out between competing groups (Collier and Hoeffler 1998, Blattman and Miguel 2011). Another looks at when an elite is forced to give up its power and extend the franchise in order to prevent a revolution (Acemoglu and Robinson 2000, 2001). The previous literature has largely overlooked the question of how the elite manipulate inefficient institutions in order to stay in power. In shedding light on this issue, our paper helps to explain the existence throughout the developing world of high levels of inequality without the consolidation of democracy or the outbreak of politically motivated violence. ${ }^{4}$

The paper's second main contribution is to show that if the country has a comparative advantage (c.a.) in primary products then trade integration tends to increase the elites' wealth and this increases the incentive for the lower classes to mount a revolution, mandating an increase in the size of the pampered bureaucracy. Therefore, by taking explicit account of the potential for social conflict, this paper presents a new explanation based on the role of institutions for how trade integration may provoke a reduction in

\footnotetext{
${ }^{4}$ Since our focus is on how the elite manipulate government employment in their own interests, we abstract from the issue of voting. Robinson, Torvik and Verdier (2006) study the incentives of governments to increase government employment using the proceeds of a natural resource boom in order to win office.
} 
economic efficiency. ${ }^{5}$

Scant attention has been paid in the prior literature to how the potential for social conflict triggered by trade integration can undermine economic performance through the manipulation of an inefficient institution. Rodrik (1999) comes close by studying the potential for social conflict that is generated by trade integration and how this conflict would be defused by the introduction of efficient institutions such as the rule of law, competitiveness of political participation, and public spending on social insurance. He shows that if these institutions could be introduced where they are absent, or made to function better, then growth would be supported. Since by contrast our pampered bureaucracy is an inefficient institution, its manipulation to maintain the status quo has the unintended consequence of undermining economic efficiency by hampering growth of the manufacturing sector.

These contributions are obtained by constructing a new model that combines a standard model of international trade with a model where one group's endowment may be expropriated by others. There are three goods: commodities, food and manufactures; commodities and food will be referred to collectively as primary products. There are three socio-economic groups within society: the elite, the middle classes and workers. The middle classes and the workers will be referred to collectively as the lower classes. And there are three factors: land, labor and human capital. Land is split into two further subcategories. The elites' wealth (i.e. their endowment) is held in their 'latifundia'; large estates of highly productive land that has been selected for its suitability to grow (or mine) a commodity. There is also an excess supply of low-grade land in the hinterlands which may be settled for free. This land is not suitable for producing the commodity but labor can be employed on this land to produce food. The elite and the workers share an endowment in common; each has a unit of labor which they can use to work in the latifundia or on low-grade land. The middle classes are endowed with human capital which

\footnotetext{
${ }^{5}$ The term 'trade integration' goes at least as far back as Heckscher (1935). In general, trade integration may be driven endogenously by tariff liberalization or exogenously by a fall in transport costs. In our model, trade integration is exogenously determined in order to focus attention on the endogenous determination of the pampered bureaucracy. As we will discuss below, the same basic results would be achieved in the more complex environment of endogenous tariff liberalization. Treating trade integration as exogenous in our theory dovetails with our econometric testing of the model which uses an exogenous gravity-based measure of trade integration to avoid endogeneity-problems that would arise under alternative measures.
} 
they can allocate to a firm that produces a manufactured good. Or, if it exists, the middle classes may alternatively choose employment in the pampered bureaucracy. This may be regarded as a short-run model in the sense that factors cannot move between sectors of production. ${ }^{6}$

A key feature of the model is that the characterization of economic equilibrium, whether under international trade or autarky, is independent of who owns which factors. This feature makes it possible to analyze the lower classes' surplus obtained from revolution, taking the economic equilibrium as given, as the outcome of a Nash bargain. If the lower classes decide to mount a revolution then ownership of the latifundia is transferred to them (at a cost), and the elite are left only with the fruits of their labor. The elite attempt to manipulate the size of the pampered bureaucracy in order to reduce to zero the surplus that the lower classes obtain from revolution and hence avert its occurrence.

The significance of the pampered bureaucracy as an institution is that it enables the elite to make publicly observable (with noise) credible commitments to transfers from itself to the rest of society through the employment contracts entailed. With specific reference to Ghana, Pellow and Chazan (1986) state that the ruling elite "had reduced the role of the state to that of a dispenser of patronage ... [and] ... established a new social stratum directly dependent on the state." The new social stratum that they refer to corresponds to what we call the pampered bureaucracy. ${ }^{7}$ In our framework the pampered bureaucracy is set up specifically for the purpose of making publicly observable transfers and in the interest of clarity plays no other role in our model. (In related contexts, more active roles are given to bureaucrats by Bhagwati 1982, Acemoglu 2005, and Acemoglu, Ticchi and Vindigni (2011) among others.)

\footnotetext{
${ }^{6}$ This framework approximates a more general framework in which both the elite and the middle classes are active in the manufacturing sector but where the middle classes are more productive. We could generalize our model in that direction and then characterize an equilibrium wherein the elite are not sufficiently productive to compete with the middle classes in manufacturing. We could endow the middle classes with labor as well, but that would complicate the model without changing the results in a meaningful way. There is no explicit role for capital in our model. Consistent with the short-run interpretation, a certain allocation of capital could be fixed in each sector without qualitatively changing our results. Reversing the endowment structure by giving human capital to the elite and land to the lower classes can make the lower classes vulnerable to expropriation by the elite as a result of trade integration.

${ }^{7}$ More broadly, such influence by the elite over public sector employment decisions is documented for Africa by Acemoglu, Johnson and Robinson (2001); for Latin America by Sokoloff and Engerman (2000); for Saudi Arabia, see State Department (1996).
} 
Our model reflects most closely the arrangements in Saudi Arabia where the royal family, which controls government, channels oil revenues directly into spending on the bureaucracy (as well as other areas of government employment) and where income taxation and capital taxation are almost non-existent. However, we take the simple structure of our model to proxy more complex arrangements in other countries. In Latin America, for example, taxation was often treated as a quid pro quo for extension of the franchise when this was restricted to the elite. Even where the extension of the franchise is now almost universal, Acemoglu and Robinson (2008) argue that the elite have often retained until today the de facto power sanctioned by these earlier arrangements. Of course, in practice there are other country-specific mechanisms through which the elite can make such credible commitments to transfers but the pampered bureaucracy appears to be one that exists across a broad range of countries. ${ }^{8}$

The main economic margin in the model is the allocation of the middle classes between entrepreneurship and the pampered bureaucracy; it is by the appropriate choice of this margin that revolution can be averted. The elite draw members of the middle classes into the pampered bureaucracy by offering them terms that are at least as good as they could obtain from entrepreneurship. The forces motivating the outcome are slightly different under autarky and free trade but the basic outcome is the same. Under autarky, there are two effects. First, elite income is used to fund the pampered bureaucracy directly so the surplus from revolution is reduced when the pampered bureaucracy is increased in size. Second, by making entrepreneurs more scarce, this raises the return both to entrepreneurship and also to a career in the pampered bureaucracy since the returns to either career path must be ex ante identical. This in turn reduces the incentive to mount a revolution. Under free trade only the first effect operates since the world price pins down the returns to entrepreneurship. But the qualitative effect of increasing the size of the pampered bureaucracy on the occurrence of revolution is the same under autarky and free trade.

\footnotetext{
${ }^{8}$ It is tempting to think that the elite could always suppress any uprising using the military instead of the pampered bureaucracy. However, the elite may fear building a bigger military lest it be coopted by the lower classes and used against them (Acemoglu, Ticchi and Vindigni 2009). This effective upper bound on the size of the military necessitates the use of other institutions such as the pampered bureaucracy to maintain political stability. We also assume that more efficient means of (lump-sum) redistribution such as land reforms are not available. One reason could be that there is an (unmodeled) scale advantage to maintaining the latifundia above a certain size.
} 
In keeping with standard predictions from trade theory, if a country in our model has relatively large endowments of land and labor, then it will tend to have a c.a. in primary products. If the country has a relatively large endowment of human capital then it will tend to have a c.a. in the production of manufactures. If a country has a c.a. in primary products then, by increasing the income of the elite, trade integration tends to mandate an increase in the size of the pampered bureaucracy in order to prevent a revolution. The reduction of efficiency entailed by an increase in the size of the pampered bureaucracy works against the standard gains from trade and, if sufficiently large (as determined by the primitives of the model), implies that trade integration may induce a reduction of economic efficiency. If a country has a c.a. in manufactures then trade integration tends to reduce the income of the elite, which in turn facilitates a reduction in the size of the pampered bureaucracy. In that case the efficiency gains that work through the reduction in the size of the pampered bureaucracy create a channel additional to the usual gains from trade through which trade integration increases economic efficiency.

From the theoretical results of our model, we develop a testable prediction which we take to the data. The key issue we face in deriving a testable prediction of our model is that the size of the pampered bureaucracy is not directly observed. ${ }^{9}$ The closest available measure of this across a reasonable range of countries and years (1972-2008 for 100 countries) is total central government spending on wages and salaries. This measure includes not only spending on the bureaucracy but also employment to carry out the legitimate functions of government which we refer to as 'structural government employment'. The way we address this issue is to introduce the identifying restriction that, while the effect of trade integration on the size of the pampered bureaucracy is determined by a country's c.a., the effect of trade integration on structural government employment is uncorrelated with a country's c.a. One motivation for this assumption is based on the 'social insurance framework' developed by Rodrik (1998, 2000). He argues that an increase in trade integration requires an increase in government spending and employment because

\footnotetext{
${ }^{9}$ There does appear to be widespread evidence to suggest that, in an attempt to quell social unrest, the elite make transfers to the rest of society through an increase of government spending. For example, The Economist (2011) documents several instances where dictators made transfers to the rest of society through government spending in response to the 'Arab Spring'; the recent wave of uprisings in the Middle East. The difficulty, which we will address through our identification strategy, is that such transfers cannot be distinguished in a direct manner from transfers made for the legitimate functions of government.
} 
the government is called upon to play a greater insurance role in response to the greater volatility of a more open economy. Note that while we assume structural government employment is unaffected by c.a., in our robustness checks we do allow for the possibility to the contrary.

The testable prediction of our model is that an increase in trade integration leads to an increase in the size of the pampered bureaucracy in countries with a c.a. in primary products relative to those with a c.a. in manufactures. Our paper's third main contribution is to present econometric results that support this prediction across a variety of specifications. We first present evidence that the prediction holds in a regression that pools all countries in our sample. We then allow for heterogeneity by level of development. As one might expect, we find stronger support for our theory among developing countries. This is possibly because the institutional structure of developed countries is strong enough to prevent their elites from influencing government employment decisions and possibly because property rights can be more effectively enforced in countries that are more highly developed. ${ }^{10}$

The paper closest to ours is by Garfinkel, Skaperdas and Syropoulos (2008). In a different model to ours where competition for a natural resource takes place between two symmetrical groups, they also study potential social conflict under international trade. But they focus instead on how terms-of-trade movements can be welfare reducing in an economy that is already open. They do not show how trade integration can reduce welfare in the presence of potential social conflict as we do here. Other papers in the literature focus on the relationship between international trade and institutions but without incorporating the feature of social conflict. For example, Levchenko (2007) and Nunn (2007) model institutional differences as a source of c.a. within frameworks of incomplete con-

\footnotetext{
${ }^{10}$ The usual assumption in the literature is that the threat of revolution is more applicable to developing countries/dictatorships. Moreover, our model's feature that factor ownership is not transferrable through the market may be taken to better reflect the situation in a typical developing country. Conversely, in developed countries, markets tend to be better developed so that the lower classes are able to acquire assets backed by factors in other sectors such as the latifundia, and consequently do not support expropriation. This may help to explain why our econometric results hold better for developing rather than developed countries. However, we think a case can be made for the broader applicability of our framework to developed countries/democracies as well. It may be argued that revolution is the final backstop that underpins all political-economic systems including those in democracies. Under this interpretation, the reason we tend to observe fewer occurrences of political violence in developed countries is because the institutional structure is more supportive of the status quo.
} 
tracts and show empirically that these are an important determinant of trade flows. Do and Levchenko (2009) model institutions as fixed costs of entry in a framework where preferences over entry costs depend on firm size and are endogenously determined in a political equilibrium. In this environment, trade integration can lead to higher entry costs when it tilts political power towards a small group of large exporters who prefer to install high entry barriers. Costinot (2009) shows how the technological disparities that can underpin gains from trade are determined in part by variations in institutional quality that affect contract enforcement. Stefanides (2010) shows that in an economy with poor institutions, trade integration leads to institutional degradation. Segura-Cayuela (2006) shows how trade integration frees the elite from adverse general equilibrium price effects when they attempt to tax and expropriate resources from the rest of society, giving them freer rein to enact extractive policies that reduce efficiency. Liu and Ornelas (2009) examine the role of trade agreements in the consolidation of democracy.

The paper is in eight sections. Section 2 sets out the basic model, determines the sequence of events and provides a definition of economic efficiency. Section 3 determines economic equilibrium under autarky and free trade respectively. The political equilibrium is determined in Section 4. It is here that the main theoretical results are presented. The paper then moves on to the empirical analysis. Section 5 presents a description of the data and some summary statistics. Section 6 develops the framework for estimation. The main econometric results are presented in Section 7. Conclusions are drawn in Section 8.

\section{The Basic Model}

We extend a standard model of international trade to allow, in a novel way, for the possibility of revolution wherein an endowment is reallocated from one group of citizens to another. Each citizen is placed in one of three socioeconomic groups: the rich elite, $r$, the middle classes, $m$, or the workers, $w$. The mass of the total population is normalized to one, and the share of each group in the population is fixed exogenously at $\lambda^{r}, \lambda^{m}>0$, and $\lambda^{w}=1-\lambda^{r}-\lambda^{m}$ respectively.

Endowments are as follows: Each member of the elite has an endowment (assumed to be positive), $L$, of latifundia (so that the total land in the latifundia is measured by $\lambda^{r} L$ ) 
and a unit endowment of labor; each member of the middle classes has an endowment (again positive), $H$, of human capital; each worker has a unit endowment of labor only. There is an unlimited amount of 'low-grade land' which is free and may be settled by anyone. If there is a revolution then the elites' latifundia are redistributed among the other groups, leaving the elite with labor only.

There are three homogeneous goods: A commodity, $c$ (think of this as being anything from coffee to gold); food, $f$; and a manufactured good, $g$. The commodity is the numeraire in the model. The price of food is denoted by $q$ and the price of manufactures is denoted by $p .^{11}$

\subsection{Production and Income}

Production of manufactures occurs as follows. Each member of the middle classes can become an entrepreneur, allocating her human capital to the set-up of a firm. A firm built with human capital $H$ produces output using a linear production technology, $g=H{ }^{12}$ Thus, for each member of the middle classes, setting up a firm yields an income from entrepreneurship, $y^{e}$, of

$$
y^{e}(p)=p H .
$$

The share of entrepreneurs in the middle classes is $\theta^{e} \in[0,1]{ }^{13}$

Members of the middle classes can be attracted to the bureaucracy by an income, $y^{b}$, that gives them a level of welfare that is at least as high as they would achieve from entrepreneurship; $v^{b} \geq v^{e}$, where $v^{i}$ is the welfare of a member of group $i$ as measured by their indirect utility function $v^{i}\left(p, y^{i}\right)$ (to be specified explicitly below). ${ }^{14}$ Denote the share of bureaucrats in the middle classes by $\theta^{b}$. Since the middle classes can either be bureaucrats or entrepreneurs, $\theta^{b}=1-\theta^{e}$.

The middle classes take $\theta^{b}$ as given, filling all available vacancies providing $v^{b} \geq v^{e}$.

\footnotetext{
${ }^{11}$ Both of these prices are measured relative to the numeraire from the outset.

${ }^{12}$ The assumption of linear production technology in manufacturing is made for simplicity and could be generalized so that output is concave in $H$ without qualitatively affecting the results.

${ }^{13}$ Thus the share of entrepreneurs in the total population is given by $\theta^{e} \lambda^{m}$. Note that parameters will be suppressed from functional notation throughout the exposition. Therefore, for example, the full functional form $y^{e}(p ; H)=p H$ is suppressed to $y^{e}(p)=p H$.

${ }^{14}$ Throughout the set-up and analysis of the model, for brevity we will drop the adjective 'pampered' and simply use the term 'bureaucracy'.
} 
Then $\theta^{e}=1-\theta^{b}$ is determined residually. At this stage we take the size of the bureaucracy, $\theta^{b}$, as given and use the model to examine the effects of an exogenous change in $\theta^{b}$. In general, $\theta^{b}$ can take any value on the unit interval $[0,1]$. However, for convenience we will adopt a baseline assumption that $\theta^{b} \in(0,1)$, which implies that we can differentiate any function that has $\theta^{b}$ as an argument in order to evaluate the implications of a change in the size of the bureaucracy. The elite choose $y^{b}$ to satisfy $v^{b}=v^{e} \cdot{ }^{15}$ Thus

$$
y^{b}(p)=p H
$$

Although bureaucrats receive an income, they are assumed not to produce anything. This is a stylized characterization of a situation where the middle classes are more productive in manufacturing than in the bureaucracy.

Production of the commodity takes place on the latifundia and requires labor. Latifundia are not used for the production of any other good in the model. ${ }^{16}$ The amount of labor employed on the latifundia is $\lambda^{c} \in\left[0, \lambda^{r}+\lambda^{w}\right]$. The (aggregate) production technology of the commodity takes the Leontief form $c=\min \left\{\lambda^{r} L, \lambda^{c}\right\} \cdot{ }^{17}$

The remaining labor, $\lambda^{r}+\lambda^{w}-\lambda^{c}$, is employed on the low-grade land where it produces food. There, a unit of labor produces a fixed quantity of output, $\underline{y}$, using low-grade land

\footnotetext{
${ }^{15}$ We assume that $y^{b}$ is chosen to yield $v^{b}=v^{e}$ for expositional purposes only, so that when it comes to the bargaining stage we can consider the middle classes as a single homogeneous group. Because we assume that each group is able to resolve its collective action problem, we are able to model the incentives of the workers and the middle classes to mount a revolution by a two-player Nash bargain. In general, the elite also consider choosing $y^{b}$ to yield $v^{b}>v^{e}$, so that a given amount of revenue results in a smaller but 'more pampered' bureaucracy. As will become clear, allowing bureaucrats and entrepreneurs to act as two separate groups within the middle classes would yield exactly the same results via a three-player Nash bargain (where again we assume that each of the - now three - groups is able to resolve its collective action problem). Note that if employment in the bureaucracy implied being coopted into the elite then expansion of the pampered bureaucracy would not serve the role of a transfer between the elite and the lower classes and so would not avert revolution. This condition would place an upper bound on $y^{b}$ when considering $v^{b}>v^{e}$. Our model could be extended to allow a subset of the bureaucrats to be coopted into the elite while the rest remained in the middle classes without changing the results qualitatively. For a model where the elite and the bureaucrats form a coalition, see Acemoglu, Ticchi and Vindigni (2011).

${ }^{16}$ This is a strong simplifying assumption that could be relaxed. All that we require is that the elite would rather produce the commodity than food, which requires in turn that the price of the commodity is sufficiently high in equilibrium. We will see that this is ensured by making the intercept of the demand curve for the commodity sufficiently large.

${ }^{17}$ The assumption of Leontief production technology is a tractable version of a more general constantelasticity-of-substitution technology wherein the elasticity of substitution between inputs is assumed to be relatively low. This assumption is an integral part of the feature of our model that economic equilibrium is determined independently of political equilibrium. This in turn will make it possible to evaluate the payoff to the lower classes of revolution in a tractable way. With a high elasticity of substitution between inputs the same qualitative results can be obtained but the analysis is significantly more complicated.
} 
(which is free because it is in excess supply) and earns a return $q \underline{y}$. Parameters are fixed such that $\lambda^{r}+\lambda^{w}>\lambda^{r} L$ and $\underline{y}$ is sufficiently low that there is excess supply of labor to the commodity sector. The market clearing price level $q$ will be determined below as part of labor- and product-market equilibrium. ${ }^{18}$ The role of the food sector in the model is to pin down the return to labor at $q \underline{y}$. This in turn puts an upper bound on payments to labor, which ensures that elite income is positive in equilibrium. ${ }^{19}$

Under the assumption that each member of the elite contributes equally towards the costs of the bureaucracy and employs his labor in his own commodity production, elite per-capita income is given by

$$
y^{r}\left(q, y^{b}, \theta^{b}\right)=L-\left(\left(\lambda^{c}-\lambda^{r}\right) q \underline{y}+\theta^{b} \lambda^{m} y^{b}\right) / \lambda^{r}
$$

The first term in brackets is the share of income that a member of the elite must pay to the workers that he hires and the second term in brackets is the per-elite-capita cost of the bureaucracy (when divided by $\lambda^{r}$ ). ${ }^{20}$

In the event of a revolution, each member of the elite retains his labor income, $q \underline{y}$; the lower classes incur a cost of mounting a revolution, $d$, and as a result of revolution the latifundia are transferred to them. ${ }^{21}$ The conditions under which a revolution may occur or be prevented will be determined in Section 4.

\footnotetext{
${ }^{18}$ In general the output of a worker on ordinary land should be determined as the outcome of an optimization decision. Here we are effectively assuming that there exists an exogenously imposed upper bound on each individual's output that is below their unconstrained optimum output level. One external constraint that could justify such an upper bound would be the ability of an individual to maintain the security of their own land. In due course we will determine an exact upper bound on $y$.

${ }^{19}$ Doing without the food sector would raise two issues. If there is more labor than can be employed on the latifundia then its return falls to zero. In that case the solution to the consumer problem is not interior for labor, introducing distracting complexities to the equilibrium solution. This also potentially implies different autarky prices under revolution and no revolution which, while possibly interesting, is not what we want to focus on. If there is less labor than can be employed on the latifundia then this potentially puts power into the hands of labor which, again, is not a feature of the situation that we want to consider here. Note that the same issues would arise if we were to merge the middle classes and the workers into a single homogenous group.

${ }^{20}$ Note that payment to a member of the elite for his own labor services has been netted out of this expression.

${ }^{21}$ Throughout our analysis, for simplicity we will treat $d$ as exogenous. An extension to endogenize $d$ would not change the results qualitatively. After the statement of Proposition 1, we will briefly explain the effects of endogenizing $d$.
} 


\subsection{Preferences and Demands}

Each member of group $i \in\{r, b, e, w\}$ has the following quasi-linear utility function:

$$
u^{i}\left(x_{c}^{i}, x_{f}^{i}, x_{g}^{i}\right)=x_{c}^{i}+x_{f}^{i}+\alpha x_{g}^{i}-\frac{1}{2}\left(x_{g}^{i}\right)^{2},
$$

where $x_{c}^{i}, x_{f}^{i}$, and $x_{g}^{i}$ are consumption of the commodity, food, and manufactures respectively by a member of group $i$ and $\alpha$ is a positive parameter. Utility is maximized subject to the budget constraint, $y^{i}=x_{c}^{i}+q x_{f}^{i}+p x_{g}^{i}$. If $y^{i} \in[0, p(\alpha-p)]$ then the consumer's problem has a corner solution wherein $x_{c}^{i}+x_{f}^{i}=0$ and $x_{g}^{i}=\frac{y^{i}}{p}$. If $y^{i}>p(\alpha-p)$ the solution to each member of group $i$ 's consumer problem is interior. In that case $x_{g}^{i}(p)=\alpha-p$, with $x_{c}^{i}$ and $x_{f}^{i}$ being determined by endowments and technology, which determine income, market clearing quantities and prices. ${ }^{22}$

Using the solutions to the consumer's problem in the utility function yields the indirect utility function, which provides the following measure of the welfare of a member of group $i, v^{i}$ :

$$
v^{i}\left(p, y^{i}\right)=\left\{\begin{array}{l}
\alpha \frac{y^{i}}{p}-\frac{1}{2}\left(\frac{y^{i}}{p}\right)^{2} \text { if } y^{i} \in[0, p(\alpha-p)] \\
y^{i}+\frac{1}{2}(\alpha-p)^{2} \text { if } y^{i}>p(\alpha-p) .
\end{array}\right.
$$

For now, assume that each group has sufficient income so that the solution to each member's consumer problem is interior. The exact conditions rely on the determination of $p$ in equilibrium. However, at this point we can say that for any given market clearing price $p$, the income of each group is underpinned by a parameter that can be varied to ensure each interiority condition is met. Specific details will be provided after the equilibrium determination of $p$. Note that for consumption of $x_{a}^{i}$ and $x_{f}^{i}$ to both be positive in the outcome of the consumer problem requires $q=1$; this will be a feature of the economic equilibrium.

When the economy is open to trade, the demand for imports is measured in the usual way as the excess of domestic demand over domestic supply and the value of exports is equal to the value of imports. However, there is no need to consider imports and exports explicitly. In the present model the gains to trade are captured through the effect of a

\footnotetext{
${ }^{22}$ The assumption that the demand curve for manufactures is linear simplifies the analysis but is not essential for our results. The utility function also exhibits the feature that the substitution elasticity between commodities and food is perfect, which could be weakened such that it is high relative to the elasticity of substitution between either of these goods and manufactures.
} 
change in the terms of trade, $p$, on $v^{i}$. We will think of trade integration as exogenous. As mentioned in the Introduction, this is to focus attention on the determination of the size of the bureaucracy. After the discussion of Proposition 2, we will consider how the model could be extended to make trade integration endogenous.

\subsection{Efficiency}

The notion of efficiency, as standard, determines the total surplus available for distribution to citizens, $\Omega$ :

$$
\Omega\left(\theta^{b}, p\right) \equiv \lambda^{r} v^{r}(p)+\lambda^{m}\left(\theta^{b} v^{b}(p)+\theta^{e} v^{e}(p)\right)+\lambda^{w} v^{w}(p) .
$$

This definition of efficiency will be useful in analyzing the implications of the various different outcomes that we will examine below.

Under the restriction that the solution to all groups' consumer problems is interior, the reduced-form expression for efficiency is as follows:

$$
\begin{aligned}
\Omega\left(\theta^{b}, p\right) \equiv & \lambda^{r} L+\left(1-\theta^{b}\right) \lambda^{m} p H+\left(\lambda^{r}+\lambda^{w}-\lambda^{r} L\right) \underline{y} \\
& +\frac{1}{2}\left(x_{g}^{i}(p)\right)^{2} .
\end{aligned}
$$

The first three terms in (2.5) measure the surplus generated by consumption of the commodity and food respectively, and the fourth term measures the surplus from consumption of manufactures.

To see the effect of a change in the size of the bureaucracy on efficiency, differentiate $\Omega\left(\theta^{b}, p\right)$ with respect to $\theta^{b}$. From $(2.5)$ we obtain:

$$
\frac{d \Omega\left(\theta^{b}, p\right)}{d \theta^{b}}=-\lambda^{m} p H<0 .
$$

From this we know that the bureaucracy is an inefficient economic institution.

To see the effect of a change in the size of the latifundia, differentiate $\Omega\left(\theta^{b}, p\right)$ with respect to $L$. Again using (2.5) we obtain:

$$
\frac{d \Omega\left(\theta^{b}, p\right)}{d L}=(1-\underline{y}) \lambda^{r} L .
$$


For an increase of $L$ to increase efficiency requires the condition $0<\underline{y}<1$. This condition imposes an upper bound on the productivity of low-grade land so that, as the size of the latifundia are increased and labor is drawn to work on them, this raises overall surplus. Without this condition, labor could be so productive on low-grade land that the planner would shut down the latifundia and have all labor, including that of the elite, work on low-grade land. The condition $0<\underline{y}<1$ will be assumed to hold throughout.

\subsection{The Timing of Events}

The sequence of events is as follows.

1. The elite decide whether to set up a bureaucracy. If so, they choose $y^{b}$ and $\theta^{b}$.

2. Production is undertaken in manufacturing, in the latifundia, and on the low-grade land and payments are received by labor. If there is a bureaucracy, employees are recruited and receive payment.

3. The lower classes decide whether or not to mount a revolution. If they do not, factor allocations are as described above. If they do mount a revolution they incur the fixed cost, $d$, and ownership of the latifundia and commodity output are transferred from the elite to the lower classes. (The elite retain their labor income.)

4. Demands are realized, markets clear and consumption takes place.

The assumption made in stage 3 that after revolution the elite retain their labor income is made to ensure that the outcome of the consumer problem is always interior for the elite, which makes the analysis more tractable. ${ }^{23}$ Note that if entrepreneurs have an incentive to mount or support a revolution then so do bureaucrats, the latter being rewarded for their support of the revolution at least in part by retention of their jobs in the bureaucracy.

\footnotetext{
${ }^{23}$ This assumption has some basis in recent experience as well. For example, white farmers who were displaced from their farms as part of recent land reforms in Zimbabwe in many instances now work on those farms as foremen or laborers (The Economist 2010).
} 


\section{Economic Equilibrium}

We will consider economic equilibrium under autarky and free trade respectively. In an autarkic equilibrium, the price adjusts to clear the domestic market. Specifically, the autarky price, $p_{a}$, solves the market-clearing condition for manufactures:

$$
\lambda^{r} x_{g}^{r}\left(p_{a}\right)+\lambda^{m}\left(\theta^{b} x_{g}^{b}\left(p_{a}\right)+\theta^{e} x_{g}^{e}\left(p_{a}\right)\right)+\lambda^{w} x_{g}^{w}\left(p_{a}\right)=\lambda^{m} \theta^{e} H .
$$

The left hand side sums demands across groups. The right hand side gives the supply of manufactures.

Recall that (by assumption for now) $x_{g}^{i}(p)=\alpha-p$ for $i \in\{r, b, e, w\}$. Using the fact that the mass of the total population is normalized to one, write the autarky market clearing condition for manufactures as $\alpha-p_{a}=\left(1-\theta^{b}\right) \lambda^{m} H$, from which the autarky market clearing price is

$$
p_{a}=\alpha-\left(1-\theta^{b}\right) \lambda^{m} H .
$$

Setting a lower bound on $\alpha$ at $\underline{\alpha} \equiv\left(1-\theta^{b}\right) \lambda^{m} H$ ensures that $p_{a}>0$ for all $\alpha>\underline{\alpha}$. Note that $p_{a}$ is increasing in $\theta^{b}$. Intuitively, increasing the size of the bureaucracy reduces the output of manufactures and thus pushes up their price. By (2.1) and (2.2), an increase in $p$ increases both $y^{e}$ and $y^{b}$. So in autarky the elite can raise the payoff to the middle classes of maintaining the status quo by increasing the size of the bureaucracy and thus make revolution less attractive.

Under free trade, and because this is a small country, the world price $p_{w}$ is taken as given. It is also assumed that the rest of the world produces and consumes both commodities and food; all goods can be traded. By definition, a country produces relatively cheaply the good for which it has a c.a.. So a c.a. in the commodity or food would imply $p_{w}<p_{a}$; a c.a. in manufactures would imply $p_{w}>p_{a}$. Accordingly, we will assume that the world price lies within an interval $p_{w} \in\left[p_{a} \pm v\right]$. To ensure that $p_{w}>0$ requires the following modification to the restriction on $\alpha$ identified above; we now require $\alpha>v+\underline{\alpha} .{ }^{24}$ This condition will be assumed to hold throughout. Domestic demand for imports is greater at $p_{w}$ and so imports are obviously positive under free trade. Trade is

\footnotetext{
${ }^{24}$ The model could easily be extended, although without adding insight to what we are doing here, to determine endogenously the difference between $p_{a}$ and $p_{w}$ as a reflection of differences in average factor endowments across countries.
} 
balanced in free trade equilibrium so there is an equal value of exports to clear the trade account.

We can now characterize economic equilibrium as follows.

Lemma 1 (Characterization of Economic Equilibrium). There exist ranges of $v$ and $\lambda^{m}$ sufficiently small and ranges of $H$ and $L$ sufficiently large that in economic equilibrium, whether under autarky or free trade, the solution to the consumer problem for each group $i \in\{r, b, e, w\}$ is interior and $q=1$.

The proof of Lemma 1 is in two parts. The first part establishes the conditions for which $y^{i}>p(\alpha-p)$ for any $p \in\left[p_{a} \pm \nu\right]$ and for each $i \in\{r, b, e, w\}$. We take $y^{b}$ and $y^{e}$ first since the argument is easiest to establish for these two. Since the incomes of entrepreneurs and bureaucrats are underpinned by their endowments of human capital, the condition is satisfied for $H$ sufficiently large. To ensure that the condition is met for $y^{w}$ we impose a condition on $\lambda^{m}$ that limits the size of $p(\alpha-p) .{ }^{25}$ Finally, by $(2.3), y^{r}$ depends positively on $L$ which is otherwise unrestricted and can simply be increased without bound to ensure that the condition $y^{r}>p(\alpha-p)$ is met. Henceforth it will be assumed that $v$ and $\lambda^{m}$ are sufficiently small and $H$ and $L$ sufficiently large to ensure that the consumer problem for each group is indeed interior in economic equilibrium.

The second part of the proof establishes that the markets for all three goods clear in autarky at $p=p_{a}$ and $q=1$. It establishes that any perturbation of equilibrium results in a restoration of equilibrium at $q=1$ both through the labor market and the goods market. Then given $q=1$, by Walras' law, $p=p_{a}$ ensures that all markets clear. Providing $p \in\left[p_{a} \pm \nu\right]$, the same holds under trade integration.

The efficiency implications of trade integration can be evaluated in a straightforward way using (2.5) to obtain a reduced-form expression for $\Omega$ in autarky, and then differentiating this with respect to $p$ in order to evaluate the gains from trade. Use in (2.5) the

\footnotetext{
${ }^{25}$ Since in general $y^{w}=q y$, and there is an upper bound of unity on $y$, for any given $q$ we need to limit the size of $p(\alpha-p)$ in order to ensure that $y^{w}>p(\alpha-p)$. This is achieved by imposing an upper bound on $\lambda^{m}$. To see this first note that $p(\alpha-p)=p x_{g}$, where the right hand side is decreasing in $\lambda^{m}$ for $\lambda^{m}$ sufficiently small since a smaller $\lambda^{m}$ makes $x_{g}$ more scarce, hence increasing $p$ towards $\alpha$ from below. There will thus exist a size of $\lambda^{m}$ sufficiently small that $y^{w}>p x_{g}$, so that $x_{c}, x_{f}>0$ and the solution to $w$ 's problem is interior.
} 
fact that $x_{g}^{i}\left(p_{a}\right)=\alpha-p_{a}$ for $i \in\{r, b, e, w\}$ to obtain

$$
\begin{aligned}
\Omega\left(\theta^{b}, p\right) \equiv & \lambda^{r} L+\left(1-\theta^{b}\right) \lambda^{m} p H+\left(\lambda^{r}+\lambda^{w}-\lambda^{r} L\right) \underline{y} \\
& +\frac{1}{2}(\alpha-p)^{2} .
\end{aligned}
$$

Differentiating this expression with respect to $p$,

$$
\frac{d \Omega\left(\theta^{b}, p\right)}{d p}=\left(1-\theta^{b}\right) \lambda^{m} H-(\alpha-p) .
$$

From this expression we find that, whether the country has a c.a. in manufactures or primary products, trade integration always raises efficiency. To see this use (3.1) to substitute the reduced form of $p_{a}$ for $p$, and note that $d \Omega\left(\theta^{b}, p\right) /\left.d p\right|_{p=p_{a}}=0$, while $\partial^{2} \Omega\left(\theta^{b}, p\right) / \partial p^{2}=1$. Thus, efficiency obtains a minimum in autarky. Given this structure observe how the condition above that ensures $p_{a}>0$ also ensures that efficiency increases whether the country has a c.a. in primary products (in which case trade integration implies $p>p_{a}$ ) or a c.a. in manufactures (in which case trade integration implies $p<$ $\left.p_{a}\right)$. Trade integration, either as an incremental step away from autarky or a move right from autarky to free trade, thus implies an increase in efficiency whether the country has a c.a. in primary products or manufactures. This result will serve as a useful benchmark against which to compare the efficiency implications of trade integration when the size of the bureaucracy is endogenous.

We can also evaluate the effects of trade integration on individual factor rewards and see that the Stolper-Samuelson theorem holds in our model (although not strictly for $w$ ): $d y^{e} / d p=H$ while $d y^{r} / d p=-\theta^{b} \lambda^{m} H / \lambda^{r}$ and $d y^{w} / d p=0$. That is, an increase in the (relative) price of manufactures, $p$, leads to an increase in the (nominal and real) income of entrepreneurs, and the condition $v^{b}=v^{e}$ implies that the income of bureaucrats must increase as well. This also implies a fall in the income of the elite, and no change in the income of workers. The converse holds for a fall in $p$. The welfare implications are less immediate but are consistent with the Stolper-Samuelson. First, $d v^{b} / d p=d v^{e} / d p=$ $H-(\alpha-p)$. The proof of Lemma 1 (in Appendix A.1) establishes that the condition on $H$ is precisely $H>(\alpha-p)$, and it follows that an increase in $p$ makes entrepreneurs and bureaucrats better off. On the other hand, $d v^{r} / d p=-(\alpha-p)-\theta^{b} \lambda^{m} H / \lambda^{r}$ while $d v^{w} / d p=-(\alpha-p)$ which are both negative (given $\alpha>v+\underline{\alpha}$ ) again as we should expect, 
so that a rise in the price of the commodity or food, captured by a fall in $p$, would make the elite and workers better off. (See part (ii) of the proof of Lemma 1 for further details of how $q$ adjusts to clear the market for food.)

\section{Political Equilibrium}

Assume that each group within the lower classes, the middle classes and the workers respectively, is able to resolve the collective action problem inherent in the decision over whether or not to revolt. The objective of the elite will be to reduce the surplus from revolution to zero through its manipulation of the size of the bureaucracy, thus removing the incentive to revolt.

The aim is now to establish that there exists a value of $\theta^{b}$ that would reduce the surplus from revolution to zero, where the surplus is given by the total value of elite net income (less their return to labor) after production has taken place minus the cost of mounting a revolution. We will say that such a value of $\theta^{b}$ satisfies the no-revolutionconstraint $(N R C)$, and refer to this value as $\tilde{\theta}^{b}$, where $N R C$ is written formally as follows: ${ }^{26}$

$$
\begin{aligned}
N R C: & h\left(\tilde{\theta}^{b}, p\right)=\lambda^{r} y^{r}\left(\tilde{\theta}^{b}, p\right)-d \\
= & \lambda^{r}(L-(L-1) \underline{y})-\tilde{\theta}^{b} \lambda^{m} p H-d=0 .
\end{aligned}
$$

We will use (4.1) to study $\tilde{\theta}^{b}$ in the next subsection.

\subsection{The Equilibrium Size of the Pampered Bureaucracy}

It is instructive to solve for $\tilde{\theta}^{b}$ first under free trade and then under autarky. Under free trade, take $p$ as given and obtain $\tilde{\theta}^{b}$ by rearranging (4.1):

$$
\widetilde{\theta}^{b}(p)=\frac{\lambda^{r}(L-(L-1) \underline{y})-d}{\lambda^{m} p H} .
$$

For $\tilde{\theta}^{b}$ to satisfy $N R C$, it must lie in the interval $(0,1]$. If the solution lies at or below zero then this implies that $d$ is too large relative to $\lambda^{r} y^{r}\left(\theta^{b}, p\right)$ for a revolution to be worth

\footnotetext{
${ }^{26}$ Since our focus is on the existence of a value of $\theta^{b}$ that brings the surplus from revolution to zero, we do not need to worry about how the surplus would be divided between $i \in\{m, w\}$ if it were positive. It would reflect the relative incomes received by the respective groups in the status quo if the revolution failed. See Appendix A.2 for a full derivation of the NRC.
} 
while. From (4.2), an increase in $d$ makes this more likely. If the solution is greater than one then the $N R C$ cannot be satisfied for any value of $\tilde{\theta}^{b}$ and there is nothing that the elite can do (within the context of the present model) to prevent revolution. For $\underline{y} \in[0,1)$, an increase in $L$ makes this more likely. An increase in the cost of revolution tightens the $N R C$ while an increase in the value of the latifundia increases the payoff to revolution and hence relaxes the $N R C$.

Let us now establish the conditions for which there exists a solution $\widetilde{\theta}^{b} \in(0,1]$ under autarky. Substituting (3.1) into (4.1),

$$
\begin{aligned}
& h\left(\theta^{b}, p_{a}\right)=\lambda^{r} y^{r}\left(\theta^{b}, p_{a}\right)-d \\
= & \lambda^{r}(L-(L-1) \underline{y})-\theta^{b} \lambda^{m} H\left(\alpha-\left(1-\theta^{b}\right) \lambda^{m} H\right)-d .
\end{aligned}
$$

Conditions under which there exists a solution $\widetilde{\theta}^{b} \in(0,1]$ can be obtained by the intermediate value theorem. Using values $\theta^{b}=0$ and $\theta^{b}=1$, by inspection of (4.3), the following endpoints of $h\left(\theta^{b}, p\right)$ are determined:

$$
\begin{aligned}
& h\left(0, p_{a}\right)=\lambda^{r}(L-(L-1) \underline{y})-d ; \\
& h\left(1, p_{a}\right)=\lambda^{r}(L-(L-1) \underline{y})-d-\alpha \lambda^{m} H .
\end{aligned}
$$

Thus, given $\lambda^{r}$, if $L$ is sufficiently large relative to $d$ then $h\left(0, p_{a}\right)>0$. Make $H$ sufficiently large as to ensure that $h\left(1, p_{a}\right)<0$. Since $h\left(\theta^{b}, p\right)$ is a continuous function of $\theta^{b}$, there must exist a value $\tilde{\theta}^{b}$ that satisfies $h\left(\theta^{b}, p_{a}\right)=0$. Therefore we can characterize political equilibrium in autarky:

Proposition 1 (Characterization of Political Equilibrium in Autarky). There exist ranges of $d$ sufficiently small and $H$ sufficiently large that in the autarky equilibrium the equilibrium size of the pampered bureaucracy, i.e. the (unique) value $\tilde{\theta}^{b} \in(0,1]$ satisfying the NRC, prevents a revolution.

The restrictions on $d$ and $H$ are imposed to ensure that $h\left(0, p_{a}\right)>0$ and $h\left(1, p_{a}\right)<0$. The proof of this result shows that the first derivative of $h\left(\theta^{b}, p\right)$ is negative with respect to $\theta^{b}$, thus establishing that $\tilde{\theta}^{b}$ is unique (see Appendix A.1). This result shows that, providing the cost of mounting a revolution is not too large, and that there is sufficient human capital, it is always both possible and in their interests for the elite to expand the 
size of the pampered bureaucracy to the point where a revolution is not worth while for the lower classes. If $d$ is too large relative to $L$ then the relatively high cost of mounting a revolution, or equivalently the damage done by it, means that it is not worth while and there is no need even to set up a pampered bureaucracy. If $H$ is too small relative to $d$ then the income paid to each bureaucrat multiplied by the share of the population in the middle classes is not large enough to reduce elite income to the point where the NRC binds. In what follows we will assume that the values of $d$ and $H$ lie in their respective ranges for which $\tilde{\theta}^{b} \in(0,1)$. The reason for not including the end-point $\widetilde{\theta}^{b}=1$ is because we will want the function characterizing $\widetilde{\theta}^{b}$ to be differentiable. ${ }^{27}$

\subsection{The Effects of Trade Integration on the Pampered Bureaucracy}

Having now determined the size of a bureaucracy that prevents a revolution in autarky, if a pampered bureaucracy exists we can examine the effects on its size of trade integration. We will focus on the case where the country has a c.a. in primary products. The logic works in reverse if the country has a c.a. in manufactures. The first step will be to show that, given $\widetilde{\theta}^{b} \in(0,1)$, trade integration as captured by a reduction of $p$ from $p_{a}$ creates an incentive to mount a revolution. The second step will be to examine how $\tilde{\theta}^{b}$ must be changed in order to prevent revolution under trade integration.

Differentiating the $N R C,(4.1)$, with respect to $p$,

$$
\frac{d h\left(\theta^{b}, p\right)}{d p}=-\theta^{b} \lambda^{m} H .
$$

The reduction of $p$ entailed by trade integration increases $h\left(\theta^{b}, p\right)$, establishing that trade integration generates an incentive to mount a revolution (for any given $\theta^{b}$ and $p$ and hence $\tilde{\theta}^{b}$ and $\left.p_{a}\right)$.

To calculate the change in the size of the bureaucracy mandated by trade integration, differentiate the reduced form expression for $\tilde{\theta}^{b},(4.2)$, with respect to $p$ :

$$
\frac{d \tilde{\theta}^{b}(p)}{d p}=-\frac{\lambda^{r} L-\lambda^{r}(L-1) \underline{y}-d}{\lambda^{m} p^{2} H} .
$$

\footnotetext{
${ }^{27}$ If $d$ were subject to random shocks, the choice of $\widetilde{\theta}^{b}$ would not necessarily satisfy the $N R C$ ex post. Yet even in such a stochastic environment the logic of our deterministic model would apply in that higher income among the elite would still tend to mandate a larger transfer from the elite to the lower classes through the pampered bureaucracy.
} 
Given the structure imposed on the model, $d \tilde{\theta}^{b} / d p<0$. If the country has a c.a. in primary products then trade integration mandates an increase in the size of the pampered bureaucracy in order to prevent a revolution. Intuitively, the fall in $p$ increases $y^{r}$, thus raising the surplus to the lower classes from revolution. However, from (2.3), increasing the size of the bureaucracy, $\theta^{b}$, serves to lower $y^{r}$ and with it the payoff to revolution. Providing they are not constrained by the upper bound, $\theta^{b}=1$, the elite are able to increase the size of the bureaucracy to prevent revolution in the face of trade integration. If the country has a c.a. in manufactures then, by applying the above reasoning with the signs reversed, trade integration mandates a reduction in the size of the pampered bureaucracy.

We can now examine the efficiency implications of trade integration when the size of the bureaucracy is endogenous. Recall from (4.2) that $\tilde{\theta}^{b}$ is a function of $p$. For convenience, express equation $(4.2)$ as $\tilde{\theta}^{b}(p)$. Using $\tilde{\theta}^{b}(p)$ in $(3.2)$,

$$
\begin{aligned}
\frac{d \Omega\left(\tilde{\theta}^{b}(p), p\right)}{d p}= & \left(1-\tilde{\theta}^{b}(p)\right) \lambda^{m} H-(\alpha-p) \\
& -p \lambda^{m} H \frac{d \tilde{\theta}^{b}(p)}{d p} .
\end{aligned}
$$

where now, since $\theta^{b}$ is endogenous, $\Omega$ is a function only of $p$. The first line captures the standard gains from trade and is the same as in (3.3) which was calculated for $\theta^{b}$ exogenous; recall that this is equal to zero at $p=p_{a}$ and is unaffected by the fact that now $\theta^{b}$ is chosen endogenously as a function of $p$. The second line captures the effect on efficiency of an endogenous change in the size of $\theta^{b}$; this is positive since $d \tilde{\theta}^{b} / d p<0$. Therefore trade integration for a country with a c.a. in primary products that entails a small reduction in $p$ from the autarky price, $p_{a}$, necessarily implies a reduction of economic efficiency. However, for larger reductions in $p$ the first line will be positive and may dominate the second line, so that trade integration will be efficiency increasing; observe that $\partial^{2} \Omega\left(\tilde{\theta}^{b}(p), p\right) / \partial p^{2}=1$, just as with $\theta^{b}$ exogenous. The logic is that while the standard gains from trade are relatively small in the neighborhood of autarky, they increase and ultimately overwhelm the efficiency reducing effects of changes in the size of the pampered bureaucracy. Thus we have our second main result: 
Proposition 2 (Effects of Trade Integration on Political Equilibrium). Start from an autarky equilibrium with the size of the pampered bureaucracy endogenously determined at $\widetilde{\theta}^{b} \in(0,1)$. If the country has a comparative advantage in primary products then in the region of autarky trade integration increases $\tilde{\theta}^{b}$ and hence is efficiency-reducing. If the country has a comparative advantage in manufactures then trade integration reduces $\tilde{\theta}^{b}$ and hence is always efficiency-increasing.

\section{A formal proof is in Appendix A.1. ${ }^{28}$}

It is worth reflecting on what trade integration implies for the income and welfare of the elite with $\theta^{b}$ endogenous. Using (2.2) and (2.3),

$$
\frac{d y^{r}}{d p}=-\frac{\tilde{\theta}^{b}(p) \lambda^{m}}{\lambda^{r}} H-\frac{d \tilde{\theta}^{b} / d p}{\lambda^{r}}\left(\lambda^{m}(p H)+\lambda^{r}(L-1) \underline{y}\right) .
$$

Assume the country has a c.a. in primary products. The first term of (4.6) shows that when $\theta^{b}$ is held constant a reduction of $p$ due to trade integration increases $y^{r}$. The second term tells us that the resulting increase of $\tilde{\theta}^{b}(p)$ works in the opposite direction; intuitively, the increase in elite incomes is eroded by the fact that they must pay for a larger bureaucracy to prevent revolution. Turning to the $N R C$, given that (4.1) holds before revolution, the elite must increase $\theta^{b}$ by just enough to ensure that it continues to hold after any given reduction in $p$. Therefore, given $\tilde{\theta}^{b}(p) \in[0,1]$ both before and after trade integration, there is no change in elite income, $y^{r}$. However, by (2.4), the elite still have an interest in trade integration since they enjoy a consumption gain from the fact that $p$ falls. If the country has a c.a. in manufactures then the opposite is true; with the size of the pampered bureaucracy endogenously determined and $y^{r}$ thus held constant, the elite lose from trade integration through a consumption loss as $p$ rises. Based on this property of the model it might appear that if we initially allowed the elite to control trade policy, then when the country has a c.a. in manufactures the elite would resist trade

\footnotetext{
${ }^{28}$ Proposition 2 would not necessarily change qualitatively if $d$ were endogenous. The standard assumption is that $d$ is a decreasing function of lower class income $y^{b}, y^{e}$ and $y^{w}$ based on the idea that the lower classes become better able to coordinate as their incomes rise. If the country had a c.a. in primary products then trade integration implies a reduction of $p$, which lowers $y^{b}$ and $y^{e}$. This would increase $d$, reducing the extent to which the elite have to increase $\theta^{b}$ in order to restore the $N R C$ and leaving the elite with higher income than if $d$ were exogenous. If the country had a c.a. in manufactures then the effects work in reverse. The effective upper bound placed in the size of the military discussed in the introduction, which would be imposed by the elite's fear that a large military could be used against them, would be captured formally by an upper bound on $d$ below the level required to suppress a revolution.
} 
integration. However, since revolution would also transfer control of trade policy to the lower classes, elite resistance to trade integration could generate an alternative incentive to mount a revolution.

\section{From Theory to Estimation}

We now develop an empirical analogue of (4.4), which gives the relationship between the size of the bureaucracy and trade integration. First, let $O$ denote the level of trade integration and let $C \in\{0,1\}$ be an indicator which takes a value of 0 if the country's c.a. is in manufactures and 1 if its c.a. is in primary products. Standard trade theory predicts a monotonic relationship between trade integration and the relative price of manufactures, $p$, which may be expressed as a function, $p(O)$. As noted above, if the country has a c.a. in manufactures $(C=0)$ then an increase in trade integration brings about an increase in $p$, while if the country has a c.a. in primary products $(C=1)$ then an increase in trade integration brings about a decrease in $p$. Summarizing this formally:

$$
\begin{aligned}
& \text { If } C=0 \text { then } \partial p / \partial O>0 ; \\
& \text { if } C=1 \text { then } \partial p / \partial O<0 \text {. }
\end{aligned}
$$

Denote by $A$ and $B$ the level of structural government employment and employment in the (pampered) bureaucracy respectively. Then $D \equiv A+B$, where $D$ denotes total central government spending on employment (henceforth 'total government employment'). For the purposes of exposition, for now suppose $A$ and $B$ are functions only of $p$, assuming that all other influences on government employment are subsumed in a residual term, $\varepsilon^{a}$ : $A=\hat{A}(p)+\varepsilon^{a}$ and $B=B(p)$.

Our identifying restriction is as follows. The effect of trade integration on structural

government employment is independent of c.a.; $\left.\frac{\partial A}{\partial p} \frac{\partial p}{\partial O}\right|_{C=1}=\left.\frac{\partial A}{\partial p} \frac{\partial p}{\partial O}\right|_{C=0}$. With some abuse of notation, write this more compactly as follows:

$$
\frac{\partial \hat{A}^{\pi}}{\partial O}=\frac{\partial \hat{A}^{\mu}}{\partial O}
$$

where the superscript $\pi$ denotes a country with a c.a. in primary products and the superscript $\mu$ denotes the same thing for manufactures. Notice that this formulation 
conditions on other determinants of $A$ that may be correlated with trade integration, i.e. $\varepsilon^{a}$. In principle, the causal effect of trade integration on structural government employment may be positive or negative. ${ }^{29}$

We will now show how (5.2) is helpful in deriving a testable prediction of our model. Equations (4.4) and (5.1) imply that c.a. determines the direction of the effect of a change in trade integration on the size of the pampered bureaucracy. In particular, $\left.\frac{\partial B}{\partial p} \frac{\partial p}{\partial O}\right|_{C=1}>0>\left.\frac{\partial B}{\partial p} \frac{\partial p}{\partial O}\right|_{C=0}$. Since this result is derived from a static model, we extrapolate its implication to a dynamic setting as being that, over time, $\left.\frac{\partial B}{\partial p} \frac{\partial p}{\partial O}\right|_{C=1}>\left.\frac{\partial B}{\partial p} \frac{\partial p}{\partial O}\right|_{C=0}$. We will refer to this as our main prediction. Again, with some abuse of notation, write this more compactly as:

$$
\frac{\partial B^{\pi}}{\partial O}>\frac{\partial B^{\mu}}{\partial O}
$$

We now show how the identifying restriction can be used to empirically test (5.3). First note that countries can be partitioned by c.a. and that the response of $D^{\pi}$ and $D^{\mu}$ to a change in $O$ can be measured. By the foregoing we have:

$$
\frac{\partial D^{\pi}}{\partial O}-\frac{\partial D^{\mu}}{\partial O}=\frac{\partial A^{\pi}}{\partial O}-\frac{\partial A^{\mu}}{\partial O}+\frac{\partial B^{\pi}}{\partial O}-\frac{\partial B^{\mu}}{\partial O} .
$$

Now observe that, using (5.2), a finding of $\frac{\partial D^{\pi}}{\partial O}-\frac{\partial D^{\mu}}{\partial O}>0$ implies that $\frac{\partial B^{\pi}}{\partial O}>\frac{\partial B^{\mu}}{\partial O}$, which would be evidence of our main prediction.

We difference the data to remove country-specific fixed effects. To distinguish between the effect of trade integration on the size of the bureaucracy across the two types of c.a., we interact trade integration with a dummy variable $C_{i}$ which takes a value of $C_{i}=0$ if the country has a c.a. in manufactures and $C_{i}=1$ if a country has a c.a. in primary products. This gives us the following estimating equation: ${ }^{30}$

\footnotetext{
${ }^{29}$ For example, according to Rodrik's $(1998,2000)$ social insurance framework, an increase in trade integration requires governments to play a greater insurance role in the face of increased terms of trade volatility due to world market price fluctuations; $\frac{\partial A^{\pi}}{\partial O}=\frac{\partial A^{\mu}}{\partial O}>0$. In the face of greater volatility, citizens might have a higher probability of displacement from employment. Particularly in developing countries where dedicated social security frameworks may be less well developed, this may mandate the government to play a greater role in providing social insurance in the form of government employment. However, his theory does not condition on comparative advantage. Under a competing hypothesis government employment may be called upon to play a lesser role in social insurance when increased trade integration stabilizes domestic price fluctuations through access to world markets, i.e. $\frac{\partial A^{\pi}}{\partial O}=\frac{\partial A^{\mu}}{\partial O}<0$, where again this argument does not depend on comparative advantage. Although it goes beyond the scope of our theoretical model, as a robustness check we will control for the possibility that the relationship between $A$ and $O$ is correlated with comparative advantage.

${ }^{30}$ See Appendix A.3 for a full derivation of the estimating equation.
} 


$$
\Delta D_{i, t}=\alpha_{0}+\sum_{\tau=1}^{T} \alpha_{\tau} \Delta D_{i, t-\tau}+\beta_{1} \Delta O_{i t}+\beta_{2} \Delta O_{i t} \times C_{i}+\gamma \Delta \mathbf{Z}_{i t}+\Delta \varepsilon_{i t},
$$

To understand how the estimating equation can be used to test our main prediction, focus on coefficients $\beta_{1}$ and $\beta_{2}$. Consider what $\beta_{1}$ would measure if there were no interaction term $\left(\Delta O_{i t} \times C_{i}\right)$. In that case, $\beta_{1}$ would capture the average partial effect of a change in trade integration on total government employment both through changes in structural government employment and through changes in the size of the pampered bureaucracy. Inclusion of the interaction term allows us to test the predication of our model by estimating different partial effects of trade integration by c.a.. In our specification, $\beta_{1}$ is the average partial effect of trade integration on total government employment for countries with a c.a. in manufactures, and $\beta_{1}+\beta_{2}$ is the average partial effect of trade integration on total government employment for countries with a c.a. in primary products. This is appealing because $\beta_{2}$ alone captures the difference in the average partial effect by c.a. which, according to our main prediction (5.3), is expected to be positive. Note that our framework does not make any prediction about the sign of $\beta_{1}$ since it is partly determined by the effect of trade integration on structural government employment for which existing theories offer contrasting predictions.

Our linear dynamic panel-data (DPD) formulation is attractive because it allows for persistence in the bureaucracy as well as unobserved time-invariant country-specific characteristics. Yet it is well-known that DPD models may contain unobserved effects that are correlated with the lagged dependent variable, potentially leading to inconsistency of the parameter estimates. Consistent estimates may be obtained with the Generalized Method of Moments (GMM) estimator originally proposed by Arellano and Bond (1991, henceforth referred to as $\mathrm{A} / \mathrm{B})$. This method uses the moment conditions $E\left(D_{i s} \Delta \varepsilon_{i t}\right)=0$ for time periods $s \leq t-T$, where $T$ is the terminal time period, so that $\Delta D_{i, t-1}$ may be instrumented with the lagged levels $D_{i, t-T}, D_{i, t-T-1}, \ldots$. However, lagged levels are often poor instruments for lagged differences (Arellano and Bover, 1995). Blundell and Bond (1998, henceforth $\mathrm{B} / \mathrm{B})$ show that imposing the moment conditions $E\left(\Delta D_{i t} \varepsilon_{i t}\right)=0$ and $E\left(\Delta Z_{i t} \varepsilon_{i t}\right)=0$ allows one to instrument the lagged dependent variable with the lagged differences $\Delta D_{i, t-T}, \Delta D_{i, t-T-1}, \ldots$. This procedure, by imposing stronger moment assumptions, can lead to better instrument performance. Our main analysis uses the less 
restrictive moment conditions of the $\mathrm{A} / \mathrm{B}$ estimator, but we will check our main results using the $\mathrm{B} / \mathrm{B}$ moment conditions as well.

This section concludes with a brief discussion of the estimation strategy. First, we estimate the model according to the A/B and B/B specifications using the two-step GMM estimator which is asymptotically efficient and robust to arbitrary heteroskedasticity. Second, both the $\mathrm{A} / \mathrm{B}$ and $\mathrm{B} / \mathrm{B}$ estimators are inconsistent in the presence of serial correlation, so for each estimated equation we report p-values for the test of serial correlation in the first-differenced residuals. Finally, since the estimating equation is overidentified, we will test whether the instruments are independent of the error process using the standard Hansen-Sargan approach to test the null hypothesis that the GMM criterion function is sufficiently close to zero. This latter test is commonly referred to as a test of 'instrument validity.'

\section{Data and Summary Statistics}

We measure total government employment across countries and time, $D_{i t}$, with annual data for central government spending on wages and salaries (1972-2008 in millions of real US dollars) from the International Monetary Fund's (IMF's) Government Finance Statistics database. ${ }^{31}$ A full list of countries is given in Table A1; see Appendix B.

We employ the measure of revealed c.a. $(R C A)$ due to Balassa (1965), and construct it from World Bank trade flows. ${ }^{32}$ Let $X_{i k t}$ be country $i$ 's exports of product category $k$ to the rest of the world in period $t$, and let $X_{i \omega t}$ be total exports from country $i$ to the rest of the world within a set of product categories $\omega . X_{n k t}$ is the sum of all other countries' (i.e. $j \neq i$ ) exports in product category $k$, and $X_{n \omega t}$ are total world exports in the set of product categories. Then $R C A_{i k t}=\left(X_{i k t} / X_{i \omega t}\right) /\left(X_{n k t} / X_{n \omega t}\right)$. Following the standard

\footnotetext{
${ }^{31}$ Since our estimation procedure identifies parameters using only within-variation, we need a sample whose variables exhibit significant variation across time. Fortunately, both trade integration and central government employment varied significantly during our sample period for many countries. An alternative would have been to employ data from the International Labor Organization. Unfortunately, for our purposes, these data are not nearly as comprehensive in their coverage across countries as the IMF series, especially prior to 1995 .

${ }^{32} \mathrm{An}$ alternative approach would be to assume a factor-endowments model of c.a. and proxy it with factor endowment ratios as in Nunn (2007). Yet, unlike Nunn, whose goal is to explain the determinants of c.a., we take c.a. as given and examine the implications it has for our model's prediction.
} 
approach, country $i$ has a revealed c.a. in product $k$ if and only if $R C A_{i k t}>1$. In our sample, $R C A$ is stable over time, allowing use of the mode across years as our measure of a country's c.a..

Our primary measure of trade integration is the gravity-based measure used by Rose (2004), and Gorg, Hijzen, and Munchin (2008) among others, which is the distanceweighted average of all trading partners' GDPs. First define $Y_{i t}$ as country $i$ 's GDP in year $t$ expressed in millions of constant dollars and let $\delta_{i j}$ be the distance between countries $i$ and $j$. This measure of trade integration is $\tilde{O}_{i t}=\sum_{j \neq i} Y_{j t} / \delta_{i j}$. Unlike other measures of trade integration such as tariffs and the terms of trade, which are clearly endogenous, a country's government has limited if any influence over the distance-weighted average of its trading partners' GDPs. Therefore, variation in $\tilde{O}_{i t}$ plausibly extracts identifying variation in relative prices.

For robustness we employ a common alternative measure of trade integration, which is constructed in each year for a particular country by summing its exports and imports across all trading partners and dividing by GDP. ${ }^{33}$ Although this latter measure is widely used, it is probably determined endogenously in equilibrium along with central government spending on employment. Nevertheless, it provides a useful check to our main results.

Crucial to our empirical implementation is the assumption that heterogeneity in the relationship between trade integration and total government employment across countries with a c.a. in primary products and those with a c.a. in manufactures is not confounded by other observable determinants of total government employment. To control for this possibility, first we difference the data to remove time-invariant country-specific confounders. This allows for factors that may simultaneously affect trade integration and total government employment. This approach is appealing because it allows for country-specific influences on total government employment (specifically, demographic composition, fractionalization of society along ethnic, linguistic and religious lines, levels of inequality, and the system of government) without requiring explicit measurement of these factors. This

\footnotetext{
${ }^{33}$ To construct this measure, first define $x_{i j t}$ as exports from country $i$ to country $j$ in year $t$ and $m_{i j t}$ as imports from country $j$ to country $t$ in year $t$. Total exports from and imports to country $i$ in year $t$ are given by $X_{i}=\sum_{j \neq i} x_{i j}$ and $M_{i}=\sum_{j \neq i} m_{i j}$. Then trade integration is given as $O_{i t}=$ $\left(X_{i t}+M_{i t}\right) / Y_{i t}$, which we obtained from the Penn World Tables mark 6.3. These data are available at http://pwt.econ.upenn.edu/php_site/pwt_index.php.
} 
also accounts for institutional characteristics (e.g. the protection of property rights), to the extent that these remain constant throughout our sample period. Second, an advantage of our dynamic panel data approach is that we are able to control for time-variation in individual country variation in total government employment by including lags of the dependent variable. In doing so we take as given the component of bureaucracy size that can be explained by its size in previous periods, thus indirectly capturing country-specific trends in institutions, economic development and other time-varying variables that determine changes in total government employment.

Finally, we explicitly control for observable determinants of total government employment that may be correlated with both trade integration and comparative advantage. For example, larger countries may tend to have both a c.a. in manufacturing and to experience larger responses of total government employment to changes in trade integration. To capture these country-size effects, we include total GDP expressed in millions of US dollars $\left(Y_{i t}\right)$ and population in thousands of people $\left(N_{i t}\right)$. Similarly, countries with higher incomes may tend to have higher wage rates and thus higher central government spending on wages and salaries. This may vary systematically by c.a. to the extent that countries with a c.a. in manufacturing have higher average wage rates than countries with a c.a. in primary products. An ideal measure would be middle class wage rates or the minimum wage. Since no such data exist at the annual level for a wide variety of developing countries, we use per-capita income in thousands of dollars $\left(y_{i t}\right)$. These three series came from the Penn World Tables. Additionally, since political or credit constraints may influence total government employment, especially in developing countries, we control for central government revenues $\left(R_{i t}\right)$, which are published in the IMF's Government Finance Statistics. In the robustness checks presented below, we will also construct controls related to three alternative hypotheses.

The final sample includes 100 countries and 1605 country years, so that over the 36 year period, there are an average of 16.05 observations per country. The first column of Table 1 presents summary statistics. In columns (2) and (3) we split the sample into low and high trade integration observations where high trade integration is defined as the logarithm of $\tilde{O}_{i t}$ above the mean (0.42). More open economies tend to be richer but smaller and have higher total government employment relative to less open economies. 


\section{Econometric Results}

Table 2 presents estimates of equation (5.5) in logs using the moment conditions suggested by Arellano and Bond. For brevity, we suppress the constant terms in the reported output. The first column presents results from an estimate that incorporates, on the right hand side, $\tilde{O}_{i}$ and its interaction with c.a. in primary products and two lags of the dependent variable. In all specifications, two lags of the dependent variable are sufficient to eliminate serial correlation in the differenced residuals.

The estimated coefficients on the dependent variable lags indicate that changes in total government employment are persistent. Looking across the table from the second to the fifth columns, we can see evidence that higher population, GDP, and (average) percapita income tend to translate into greater total government employment, but an increase in government revenue is associated with a decrease in total government employment, perhaps reflecting possible efficiency increases as government expands.

The covariate of interest, $\beta_{2}$, is presented in the first row. In all specifications the estimate for $\beta_{2}$, the coefficient on trade integration interacted with c.a. in primary products, is positive as predicted by our model and significant at conventional levels. This finding is evidence of our main prediction. The estimated magnitude in column (1) implies that the response in the size of the bureaucracy to changes in trade integration is 18.2 percent greater in the countries with a c.a. in primary products than for countries with a c.a. in manufactures. The second row presents estimates of $\beta_{1}$ across the various specifications. We see that the estimated sign is sensitive to model specification, but is not a concern because, as discussed above, our model does not make predictions about $\beta_{1}$.

Turning to the bottom of the table, the Sargan overidentifying restrictions test does not reject the null of instrument validity. Finally, tests of serial correlation at the bottom of the table indicate strong persistence in the levels residuals, providing support for the differenced specification, and the null of serial correlation is not rejected at the second order, indicating that the estimated model is free of serial correlation in the differenced residuals.

In Table 3, we allow for heterogeneity in the estimated effect between developed and 
developing countries as defined by the International Monetary Fund (IMF). ${ }^{34}$ The first row of the table shows that the estimated parameter values for $\beta_{2}$ are positive and significant for developing countries in all specifications. The second row shows that the estimates of $\beta_{2}$ for developed countries are smaller and in columns (3), (4) and (5) are not statistically significant suggesting that, as discussed in the Introduction, our main prediction may not hold as strongly for developed countries. Results from the specification tests are qualitatively similar to those presented in Table 2.

In Table 4, we explicitly account for three alternative explanations that might confound our results. (We have already addressed a number of alternative hypotheses about what might explain variation in total government employment by accounting for timeinvariant country level effects, country-specific trends in the size of the bureaucracy, and by including likely time-varying confounders.) The first alternative explanation is that a planned economy, in its transition to a market-based economy, may simultaneously undergo trade integration and vary total government employment. If in addition planned economies tend to disproportionately have a c.a. in manufacturing we might observe, even after accounting for country-specific fixed effects, that planned economies have (on average) a lower response of total government employment to changes in trade integration than do countries with a c.a. in primary products. To ensure that our results are not driven by this potential confounding channel, we constructed for each country a variable that takes a value of one in all years after a country made a transition to a market-based economy $\left(\right.$ post_S $\left.S_{i t}\right)$.

A second confounding channel would arise if spending on the bureaucracy was disproportionately influenced by balance-of-payments crises occurring in countries with similar comparative advantage patterns. ${ }^{35}$ We addressed this possibility by obtaining, from the IMF, data on all outstanding loans with conditionalities, for each year and for every coun-

\footnotetext{
${ }^{34}$ The aim of including the level of development in the regressions is to capture variation in underlying institutional quality. It could be argued that a preferable approach would be to use a direct measure of institutional quality like POLITY IV or the International Country Risk Guide. The reason we did not adopt this approach is because Glaeser, la Porta, Lopez-de-Silanes and Shleifer (2004) have shown that such direct measures of institutions might not in fact capture the institutional quality of a country but might instead reflect short-run choices made by politicians, either as dictators or as democratically elected representatives of government. On the other hand, there seems to be a consensus that the level of development does go some way to capturing institutional quality broadly defined.

${ }^{35}$ These crises were often addressed by obtaining IMF loans issued subject to conditionalities that typically mandated both trade liberalization and reduced government expenditures.
} 
try in our sample, and constructing a variable that takes a value of one for a particular country in those years in which it had an outstanding IMF loan to which were attached conditionalities during the previous year $\left(i m f_{i t}\right)$.

A final possibility can be derived under the null of Rodrik's social insurance framework $(1998,2000)$. This possibility may arise if countries with a c.a. in primary products experience greater terms-of-trade volatility as a result of trade integration, since production tends to be more specialized in countries with a c.a. in primary products than countries with a c.a. in manufactures. To the extent that the difference in terms-of-trade volatility by c.a. is persistent over time, we have already accounted for it with country fixed effects, but this does not rule out the possibility that the effect varies over time. As an additional test, we exploit the fact that production and export concentration tend to be correlated and constructed the Herfindahl export diversification index for each country at the annual level. ${ }^{36}$

Although the COMTRADE database, used to construct this measure, is the most comprehensive category-level trade data source available, its annual coverage is limited relative to our other data series, especially for developing countries. Nevertheless, we proceed with this limited sample. To capture the possibility that export concentration risk interacts with trade integration in a meaningful way, we also interacted the Herfindahl index with trade integration in addition to including it alone.

Table 4 reports results from the main equation re-estimated with these robustness controls included. Henceforth, we suppress lags of the dependent variable to save space. This table retains the distinction between developed and developing countries and in addition to previous controls introduces the effect of IMF conditionalities, transition from a planned to a market-based economy, the Herfindahl index and its interaction with trade integration.

From Table 4, we can see that the model's prediction is robust to the introduction

\footnotetext{
${ }^{36}$ The Herfindahl index is given by $H_{i}=\sum_{k=1}^{n}\left[\frac{x_{k t}}{x_{i}}\right]^{2}$ where $n$ is the number of different products exported, $x_{k t}$ is total exports of product $k$ in period $t$, and $x_{i}$ is total exports from country $i$ in period $t$. The Herfindahl index lies in the interval $(0,1)$, with larger values corresponding to more concentration (less diversification) of total exports. This index was constructed using SITC 4 digit product-level trade data obtained from the United Nations COMTRADE Database.
} 
of controls for these three additional hypotheses; the estimate of $\beta_{2}$ remains positive and significant for developing countries. The estimated effect is larger when these controls are included, yet this is probably due to sample attrition associated with the Herfindahl index. As before, evidence in support of the model's prediction is weaker for developed countries. The sign on the Herfindahl index is positive and significant, suggesting that the government may indeed play a greater insurance role when the economy is highly concentrated. However, the coefficient on the Herfindahl index interacted with trade integration is not significant, indicating that if the government plays an additional insurance role in responses to trade integration, its main policy instrument may not be central government employment. Perhaps surprisingly, the transition from a Soviet to a market-based economy does not appear to have had a significant effect on total (central) government employment. As predicted, the presence of an outstanding IMF loan with conditionalities tends to have a negative impact on total government employment.

Appendix B presents a number of additional robustness checks. First, in Table A2, we re-estimate equation (5.5) using the stronger B/B moment conditions. As before, the estimated coefficients on $\beta_{2}$ are significant with the predicted sign. The B/B estimator produces estimates of $\beta_{1}$ that are less stable across various specifications relative to the A/B estimator. Specification test results at the bottom of the table are qualitatively similar to those before.

In Table A3, we re-estimate (5.5) with separate average partial effects for developed and developing countries using the B/B estimator. As before, we find stronger support for the model's main prediction for developing countries than for developed countries. In this specification, the effect of government revenue is positive while the effect of population growth is netagive and, as in the previous table, the estimated coefficients on $\beta_{1}$ are sensitive to model specification.

In Table A4, we re-estimate (5.5) using the conventional trade integration measure $O_{i t}$ instead of $\tilde{O}_{i t}$, even though we believe this measure is likely to be affected by domestic policy choices. The results for $\beta_{2}$ are still positive and significant across all specifications. From the estimates of $\beta_{1}$ presented in the second row we see that, interestingly, there seems to be clearer evidence of a negative relationship between total government employment and trade integration for countries with a c.a. in manufactures. Since the trade integration 
measure is endogenous, the negative relationship might be evidence of policy initiatives to 'liberalize, privatize and stabilize' among developed countries (who overwhelmingly have a c.a. in manufactures) in the 1980 s and 1990s.

In Table A5 we re-estimate the main equation with separate average partial effects for developed and developing countries using the conventional trade integration measure. The estimates for $\beta_{2}$ are still positive and significant across all specifications. With this measure, prima facie there appears to be stronger support for the model in developed countries, but as noted before this result could be spurious since trade integration may be determined simultaneously along with total government employment.

\section{Conclusions}

In this paper, we have shown how a country's elite may be able to create a pampered bureaucracy and manipulate its size in order to maintain political stability. One effect of increasing the size of the pampered bureaucracy is to reduce the amount of surplus available for expropriation, thus making revolution less attractive. Under autarky, another effect is to make entrepreneurs more scarce and thus raise the income of the middle classes and hence their interest in maintaining the status quo. In a situation where the country has a c.a. in primary products, trade integration increases the income of the elite relative to the lower classes and thus mandates an increase in the size of the pampered bureaucracy relative to countries that have a c.a. in manufactures in order to maintain political stability. We were able to find support for this prediction in the data.

We think that the main idea of the present paper could usefully be developed in a number of directions. One would be to think about how the model could be used to motivate the social conflict that has arisen as a result of the prescriptions of condition-

ality imposed by the International Monetary Fund and World Bank. Such conditionality required that recipients of loans should 'liberalize, privatize and stabilize.' Elaborating on the first and second requirements, (the third is concerned with the macroeconomic environment and is beyond the scope of the present paper) these were for a country to reduce the size of government while liberalizing trade. The present paper suggests a new way in which an externally imposed reduction in the size of government in conjunction 
with trade liberalization may trigger social unrest in countries that have a c.a. in primary products. It would be interesting to explore this idea in greater detail.

The model of the present paper focused on one particular inefficient economic institution, the pampered bureaucracy, while regarding all other institutions as exogenous. It would be worth thinking about the interaction of the pampered bureaucracy with other institutions. Our focus on the size of the pampered bureaucracy seems reasonable, holding other institutions constant, since the elite is likely to have direct control over it and can adjust its size relatively quickly. But it would be interesting to try to capture the interactions between the pampered bureaucracy and other institutions that adjust more slowly.

\section{References}

[1] Acemoglu, D., (2005); "Politics and Economics in Weak and Strong States." Journal of Monetary Economics, 52: 1199-1226.

[2] Acemoglu, D., S. Johnson and J.A. Robinson, (2003); “An African Success Story: Botswana." Published in Dani Rodrik ed. In Search of Prosperity: Analytic Narratives on Economic Growth, Princeton; Princeton University Press.

[3] Acemoglu, D. and J.A. Robinson, (2000); "Why Did the West Extend the Franchise? Democracy, Inequality and Growth in Historical Perspective." Quarterly Journal of Economics, 115: 1167-1199.

[4] Acemoglu, D. and J.A. Robinson, (2001); "A Theory of Political Transitions." American Economic Review, 91(4): 938-963.

[5] Acemoglu, D. and J.A. Robinson, (2008); "Persistence of Powers, Elites and Institutions." American Economic Review, 98: 267-293.

[6] Acemoglu, D., D. Ticchi and A. Vindigni, (2009); "Persistence of Civil Wars." Typescript.

[7] Acemoglu, D., D. Ticchi and A. Vindigni, (2011); "Emergence and Persistence of Inefficient States." To appear in Journal of the European Economic Association. 
[8] Angrist, J. and A. Kugler, (2008); "Rural Windfall or New Resource Curse." Review of Economics and Statistics, 90: 191-215.

[9] Arellano, M. and S. Bond, (1991); "Some Tests of Specification for Panel Data: Monte Carlo Evidence and an Application to Employment Equations." Review of Economic Studies, 58(2): 277-97.

[10] Arellano, M. and O. Bover, (1995); "Another look at the instrumental variable estimation of error-components models." Journal of Econometrics 68: 29-51.

[11] Bhagwati, J.N., (1982); "Directly Unproductive, Profit-seeking (DUP) Activities." Journal of Political Economy 90(5): 988-1002.

[12] Blattman, C., and E. Miguel, (2011); "Civil War" Journal of Economic Literature 48(1): 3-57.

[13] Blundell, R. and S. Bond, (1998); "Initial conditions and moment restrictions in dynamic panel data models." Journal of Econometrics 87: 115-143.

[14] Collier, P., and A. Hoeffler (1998); "On Economic Causes of Civil War." Oxford Economic Papers, 50(4): 563-73.

[15] Costinot, A., (2009); "On the Origins of Comparative Advantage." Journal of International Economics, 77: 255-264.

[16] Do, Q.-T. and L. Iyer, (2006); "An Empirical Analysis of Civil Conflict in Nepal." Center on Institutions and Governance Working Paper No. 12, U.C. Berkeley.

[17] Do, Q.-T. and A. Levchenko, (2009); "Trade, Inequality, and the Political Economy of Institutions." Journal of Economic Theory, 144(4): 1489-1520.

[18] Dube, O. and J.F. Vargas, (2006); "The Coffee Crisis and Armed Conflict in Columbia." Harvard University typescript.

[19] The Economist (2010); "Briefing on Zimbabwe: Can Robert Mugabe Ever Be Persuaded to Give Up?" October 9th 2010: 35-38.

[20] The Economist (2011); "Throwing Money at the Street." March 12th 2011: 32. 
[21] Garfinkel, M., S. Skaperdas and C. Syropoulos, (2008); "Globalization and Domestic Conflict." Journal of International Economics.

[22] Glaeser, E.L., R. la Porta, F. Lopez de Silanes and A. Shleifer, (2005); "Do Institutions Cause Growth?" Journal of Economic Growth, 9: 271-303.

[23] Heckscher, E., (1931); Mercantilism. London. Allen \& Unwin Ltd.

[24] Hidalgo, D.N., S. Naidu, S. Nichter and N. Richardson, (2010); "Economic Determinants of Land Invasions." Review of Economics and Statistics, 92(3): 505-523.

[25] Gorg, H., A. Hijzen, and M. Manchin, (2008); "Cross-Border Mergers and Acquisitions and the Role of Trade Costs." European Economic Review 52: 849-866.

[26] Levchenko, A., (2007); "Institutional Quality and International Trade." Review of Economic Studies, 74:3 (July 2007), 791-819.

[27] Liu, X. and E. Ornelas, (2009); "Free Trade Agreements and the Consolidation of Democracy." Typescript.

[28] North, D., (1981); Structure and Change in Economic History. W.W. Norton \& Co., New York.

[29] Nunn, N., (2007); "Relationship-Specificity, Incomplete Contracts, and the Pattern of Trade," Quarterly Journal of Economics, 122(2): 569-600.

[30] Pellow, D. and N. Chazan, (1986); Ghana: Coping with Uncertainty, Westview Press, Boulder, CO.

[31] Robinson, J., R. Torvik and T. Verdier, (2006); "Political Foundations of the Resource Curse." Journal of Development Economics, 79(2): 447-468.

[32] Rodrik, D., (1998); "Why Do More Open Economies Have Bigger Governments?" Journal of Political Economy, 106(5), 997-1032.

[33] Rodrik, D., (1999); "Where Did All the Growth Go? External Shocks, Social Conflict and Growth Collapses." Journal of Economic Growth, 4: 385-412. 
[34] Rodrik, D., (2000); "What Drives Public Employment in Developing Countries?" Review of Development Economics, 4(3): 229-243.

[35] Rose, A., (2004); “Do WTO Members Have More Liberal Trade Policy?” Journal of International Economics, 63: 209-235.

[36] Sachs, J.D. and A.M. Warner, (2001); "The Curse of Natural Resources." European Economic Review, 45: 827-838.

[37] Segura-Cayuela, R. (2006); "Inefficient Policies, Inefficient Institutions and Trade." Bank of Spain Working Paper no. 0633

[38] Sokoloff, K.L. and S.L. Engerman, (2000); "History Lessons: Institutions, Factor Endowments, and Paths of Development in the New World." Journal of Economic Perspectives, 14(3): 217-232.

[39] Stefanides, C. (2010); “Appropriation, Property Rights Institutions, and International Trade." American Economic Journal: Economic Policy, 2(4): 148-72.

[40] Varma, P., (1998); The Great Indian Middle Class. Viking/Penguin Press. 


\begin{tabular}{|c|c|c|c|c|}
\hline & $\begin{array}{c}\text { All } \\
\text { Countries } \\
(1)\end{array}$ & $\begin{array}{l}\text { Low } \\
\text { T.I. } \\
(2)\end{array}$ & $\begin{array}{c}\text { High } \\
\text { T.I. } \\
(3)\end{array}$ & $\begin{array}{c}\text { P-value } \\
\text { (2) vs. (3) } \\
(4)\end{array}$ \\
\hline $\begin{array}{c}\text { Number of countries } \\
\text { Means }\end{array}$ & 100 & 59 & 41 & - \\
\hline$D_{i t}$ & $\begin{array}{c}508.96 \\
(508.96)\end{array}$ & $\begin{array}{c}205.18 \\
(305.37)\end{array}$ & $\begin{array}{c}670.17 \\
(928.81)\end{array}$ & 0.001 \\
\hline$Y_{i t}$ & $\begin{array}{c}5075.3 \\
(6266.0)\end{array}$ & $\begin{array}{c}2551.6 \\
(3698.2)\end{array}$ & $\begin{array}{c}8038.0 \\
(7325.0)\end{array}$ & 0.000 \\
\hline$R_{i t}$ & $\begin{array}{c}908.45 \\
(3813.3)\end{array}$ & $\begin{array}{c}964.91 \\
(4810.3)\end{array}$ & $\begin{array}{c}841.28 \\
(2174.7)\end{array}$ & 0.872 \\
\hline$N_{i t}$ & $\begin{array}{c}28985 \\
(91472)\end{array}$ & $\begin{array}{c}33726 \\
(118153)\end{array}$ & $\begin{array}{c}23419 \\
(43670)\end{array}$ & 0.577 \\
\hline$y_{i t}$ & $\begin{array}{c}3603.4 \\
(12744)\end{array}$ & $\begin{array}{c}2902.1 \\
(11499)\end{array}$ & $\begin{array}{c}4426 \\
(14269)\end{array}$ & 0.553 \\
\hline Proportion & & & & \\
\hline$r c a_{p}$ & $\begin{array}{c}0.598 \\
(0.450)\end{array}$ & $\begin{array}{c}0.630 \\
(0.439)\end{array}$ & $\begin{array}{c}0.561 \\
(0.466)\end{array}$ & 0.450 \\
\hline
\end{tabular}

Column (1) reports average country characteristics for the entire sample. Columns (2) and (3) report average country characteristics for countries with low and high trade integration where which is defined as trade integration above the mean (0.42). $D_{i t}, Y_{i t}, R_{i t}$ and $y_{i t}$ are in domestic currency units. $\mathrm{N}_{i t}$ is the population in thousands, rca $_{p}$ denotes r.c.a. in primary products. $\operatorname{imf}_{i t}$ takes a value of 1 if a country has an outstanding IMF loan in period $t$. post_S $\mathrm{S}_{i t}$ takes a value of 1 for all years in which a country is classified as post-Soviet. 


\section{Table 2. Determinants of Total Government Employment Spending}

$(1)$

(2)

$0.182^{* * *}$

$0.127^{* * *}$

(3)

(0.006)

$(0.011)$

$0.129^{* * *}$

$(4)$

$(5)$

Trade integration (t)

$\times$ primary

$0.477^{* * *}$

(0.045)

$0.515^{* * *}$

$(0.017)$

$0.116^{* * *}$

$0.131^{* * *}$

Trade integration (t)

(0.051)

$-1.093^{* * *}$

$(0.021)$

(0.020)

Population (t)

$0.364^{* * *}$

(0.068)

$-1.395^{* * *}$

$-0.903^{* * *}$

(0.056)

$0.521^{* * *}$

(0.069)

(0.113)

Population (t)

Government revenue (t)

$-5.47 \mathrm{e}-07^{* * *}$

(0.035)

$0.552^{* * *}$

(0.034)

$0.559^{* * *}$

(0.027)

(5.42e-08)

$-2.72 \mathrm{e}-07^{* * *}$

(3.43e-08)

GDP (t)

$0.784^{* * *}$

$0.758^{* * *}$

(0.0066)

(0.0245)

Per-capita income (t)

$\Delta B_{i, t-1}$

$0.989 * * *$

$0.999^{* * *}$

$0.350^{* * *}$

$0.710^{* * *}$

$0.401^{* * *}$

(0.009)

(0.013)

(0.013)

(0.009)

(0.018)

$\Delta B_{i, t-2}$

$-0.120^{* * *}$

$-0.161^{* * *}$

$-0.059^{* * *}$

$-0.134^{* * *}$

$-0.090^{* * *}$

(0.006)

(0.009)

(0.006)

(0.007)

(0.007)

Sargan Test (p-value)

1.000

1.000

1.000

1.000

1.000

Serial correlation:

1st order ( $p$-value)

0.001

0.000

0.001

0.001

0.380

0.752

0.000

0.098

1346

1346

92

92

1253

92

89

0.264

Number of id

1346

This table presents dynamic panel data esimates of the determinants of annual spending on the bureaucracy (described in section 3). Columns (1) - (4) report estimates from the A/B estimator using $\tilde{\mathrm{O}}_{i t}$ described in Section 3. Sargan overidentifying test p-values and tests of 2 nd order autocorrelation are reported below regression results. Constants suppressed. Two step optimal GMM standard errors are reported in parentheses *, ** and $* * *$ denote statistical significance at the $10 \%, 5 \%$ and $1 \%$ levels. 
Table 3. Determinants of Total Government Employment Spending; Countries Differentiated by Level of Development

\begin{tabular}{|c|c|c|c|c|c|}
\hline & (1) & $(2)$ & $(3)$ & (4) & $(5)$ \\
\hline $\begin{array}{l}\text { Trade integration }(\mathrm{t}) \\
\times \text { primary } \times \text { developing }\end{array}$ & $\begin{array}{c}0.281^{* * *} \\
(0.046)\end{array}$ & $\begin{array}{c}0.209^{* * *} \\
(0.071)\end{array}$ & $\begin{array}{c}0.181^{* * *} \\
(0.050)\end{array}$ & $\begin{array}{c}0.190^{* * *} \\
(0.041)\end{array}$ & $\begin{array}{l}0.130 * * \\
(0.061)\end{array}$ \\
\hline $\begin{array}{l}\text { Trade integration }(\mathrm{t}) \\
\times \text { primary } \times \text { developed }\end{array}$ & $\begin{array}{c}0.113^{* * *} \\
(0.0202)\end{array}$ & $\begin{array}{c}0.122^{* *} \\
(0.055)\end{array}$ & $\begin{array}{c}0.016 \\
(0.025)\end{array}$ & $\begin{array}{c}0.040 \\
(0.074)\end{array}$ & $\begin{array}{l}0.0353 \\
(0.039)\end{array}$ \\
\hline $\begin{array}{l}\text { Trade integration }(\mathrm{t}) \\
\times \text { developing }\end{array}$ & $\begin{array}{c}0.175 \\
(0.142)\end{array}$ & $\begin{array}{c}0.614^{* * *} \\
(0.158)\end{array}$ & $\begin{array}{c}0.075 \\
(0.445)\end{array}$ & $\begin{array}{c}-1.095^{* * *} \\
(0.273)\end{array}$ & $\begin{array}{c}-0.368^{* *} \\
(0.182)\end{array}$ \\
\hline $\begin{array}{l}\text { Trade integration }(\mathrm{t}) \\
\times \text { developed }\end{array}$ & $\begin{array}{c}0.454^{* * *} \\
(0.078)\end{array}$ & $\begin{array}{c}0.534^{* * *} \\
(0.062)\end{array}$ & $\begin{array}{c}-1.262^{* * *} \\
(0.222)\end{array}$ & $\begin{array}{c}-1.554^{* * *} \\
(0.152)\end{array}$ & $\begin{array}{c}-1.598^{* * *} \\
(0.123)\end{array}$ \\
\hline Population (t) & & $\begin{array}{c}0.363^{* * *} \\
(0.060)\end{array}$ & $\begin{array}{c}0.441^{* * *} \\
(0.045)\end{array}$ & $\begin{array}{c}0.505^{* * *} \\
(0.048)\end{array}$ & $\begin{array}{c}0.259^{* * *} \\
(0.072)\end{array}$ \\
\hline Government revenue $(\mathrm{t})$ & & $\begin{array}{c}-5.14 \mathrm{e}-07^{* * *} \\
(6.52 \mathrm{e}-08)\end{array}$ & & & $\begin{array}{c}6.99 \mathrm{e}-08 \\
(5.51 \mathrm{e}-08)\end{array}$ \\
\hline $\operatorname{GDP}(\mathrm{t})$ & & & $\begin{array}{c}0.799^{* * *} \\
(0.008)\end{array}$ & & $\begin{array}{c}0.730^{* * *} \\
(0.025)\end{array}$ \\
\hline Per-capita income (t) & & & & $\begin{array}{c}1.063^{* * *} \\
(0.026)\end{array}$ & $\begin{array}{l}0.0180 \\
(0.038)\end{array}$ \\
\hline$\Delta B_{i, t-1}$ & $\begin{array}{c}1.003^{* * *} \\
(0.011)\end{array}$ & $\begin{array}{c}0.998^{* * *} \\
(0.012)\end{array}$ & $\begin{array}{c}0.332^{* * *} \\
(0.015)\end{array}$ & $\begin{array}{c}0.710^{* * *} \\
(0.008)\end{array}$ & $\begin{array}{c}0.446^{* * *} \\
(0.014)\end{array}$ \\
\hline$\Delta B_{i, t-2}$ & $\begin{array}{c}-0.123^{* * *} \\
(0.008)\end{array}$ & $\begin{array}{c}-0.157^{* * *} \\
(0.007)\end{array}$ & $\begin{array}{c}-0.054^{* * *} \\
(0.008)\end{array}$ & $\begin{array}{c}-0.136^{* * *} \\
(0.008)\end{array}$ & $\begin{array}{c}-0.107^{* * *} \\
(0.012)\end{array}$ \\
\hline $\begin{array}{l}\text { Sargan Test (p-value) } \\
\text { Serial correlation: }\end{array}$ & 1.000 & 1.000 & 1.000 & 1.000 & 1.000 \\
\hline $\begin{array}{l}\text { 1st order (p-value) } \\
\text { 2nd order (p-value) }\end{array}$ & $\begin{array}{l}0.001 \\
0.242\end{array}$ & $\begin{array}{l}0.000 \\
0.089\end{array}$ & $\begin{array}{l}0.000 \\
0.289\end{array}$ & $\begin{array}{l}0.001 \\
0.754\end{array}$ & $\begin{array}{l}0.000 \\
0.719\end{array}$ \\
\hline $\begin{array}{l}\text { Observations } \\
\text { Number of id }\end{array}$ & $\begin{array}{l}1346 \\
92\end{array}$ & $\begin{array}{l}1253 \\
89\end{array}$ & $\begin{array}{l}1346 \\
92\end{array}$ & $\begin{array}{l}1346 \\
92\end{array}$ & $\begin{array}{c}1253 \\
89\end{array}$ \\
\hline
\end{tabular}

This table presents dynamic panel data esimates of the determinants of annual spending on the bureaucracy (defined in Section 3). Columns (1) - (4) report A/B estimates using $\tilde{\mathrm{O}}_{i t}$ as described in Section 3. Sargan overidentifying test p-values and tests of $2 \mathrm{nd}$ order autocorrelation are reported below regression results. Constants are suppressed for brevity. Two step optimal GMM Standard errors are reported in parentheses. ${ }^{*}, * *$ and $* * *$ denote statistical significance at the $10 \%, 5 \%$ and $1 \%$ levels. 


\begin{tabular}{|c|c|c|c|c|}
\hline & $(1)$ & $(2)$ & $(3)$ & $(4)$ \\
\hline $\begin{array}{l}\text { Trade integration }(\mathrm{t}) \times \text { primary } \\
\times \text { developing }\end{array}$ & $\begin{array}{c}0.512^{* * *} \\
(0.114)\end{array}$ & $\begin{array}{c}0.510^{* * *} \\
(0.116)\end{array}$ & $\begin{array}{c}0.377^{* * *} \\
(0.113)\end{array}$ & $\begin{array}{l}0.245^{* *} \\
(0.114)\end{array}$ \\
\hline $\begin{array}{l}\text { Trade integration }(\mathrm{t}) \times \text { primary } \\
\times \text { developed }\end{array}$ & $\begin{array}{c}0.118^{* * *} \\
(0.035)\end{array}$ & $\begin{array}{c}0.142^{* * *} \\
(0.039)\end{array}$ & $\begin{array}{c}0.165^{* * *} \\
(0.043)\end{array}$ & $\begin{array}{l}-0.017 \\
(0.052)\end{array}$ \\
\hline Trade integration $(\mathrm{t}) \times$ developing & $\begin{array}{c}0.411 \\
(0.549)\end{array}$ & $\begin{array}{l}1.406^{*} \\
(0.846)\end{array}$ & $\begin{array}{c}2.482^{* * *} \\
(0.848)\end{array}$ & $\begin{array}{c}0.121 \\
(1.777)\end{array}$ \\
\hline Trade integration $(\mathrm{t}) \times$ developed & $\begin{array}{c}0.774^{* * *} \\
(0.186)\end{array}$ & $\begin{array}{c}0.598^{* * *} \\
(0.181)\end{array}$ & $\begin{array}{c}0.522^{* *} \\
(0.220)\end{array}$ & $\begin{array}{c}-1.238^{* * *} \\
(0.386)\end{array}$ \\
\hline Population $(\mathrm{t})$ & & & & $\begin{array}{c}0.142 \\
(0.132)\end{array}$ \\
\hline Government revenue $(\mathrm{t})$ & & & & $\begin{array}{c}1.07 \mathrm{e}-07 \\
(1.12 \mathrm{e}-07)\end{array}$ \\
\hline GDP $(\mathrm{t})$ & & & & $\begin{array}{c}0.774^{* * *} \\
(0.087)\end{array}$ \\
\hline Per-capita income $(\mathrm{t})$ & & & & $\begin{array}{l}-0.058 \\
(0.151)\end{array}$ \\
\hline Outstanding IMF loan (t) & & & $\begin{array}{l}-0.087 \\
(0.136)\end{array}$ & $\begin{array}{c}-0.112^{* *} \\
(0.047)\end{array}$ \\
\hline Post-Soviet (t) & & $\begin{array}{l}-0.069 \\
(0.375)\end{array}$ & $\begin{array}{l}-0.392 \\
(0.412)\end{array}$ & $\begin{array}{l}-0.023 \\
(0.355)\end{array}$ \\
\hline Trade integration $\times$ Herfindahl $(\mathrm{t})$ & $\begin{array}{c}0.026 \\
(0.031)\end{array}$ & $\begin{array}{c}0.029 \\
(0.037)\end{array}$ & $\begin{array}{l}-0.025 \\
(0.030)\end{array}$ & $\begin{array}{l}-0.052 \\
(0.052)\end{array}$ \\
\hline Herfindahl $(\mathrm{t})$ & $\begin{array}{c}0.046 \\
(0.043)\end{array}$ & $\begin{array}{c}0.046 \\
(0.045)\end{array}$ & $\begin{array}{c}0.114^{* *} \\
(0.050)\end{array}$ & $\begin{array}{c}0.131^{* *} \\
(0.060)\end{array}$ \\
\hline Sargan Test (p-value) & 1.00 & 1.00 & 1.00 & 1.00 \\
\hline $\begin{array}{l}\text { Serial correlation: } \\
\text { 1st order (p-value) } \\
\text { 2nd order ( } p \text {-value) }\end{array}$ & $\begin{array}{l}0.000 \\
0.320\end{array}$ & $\begin{array}{l}0.000 \\
0.346\end{array}$ & $\begin{array}{l}0.000 \\
0.370\end{array}$ & $\begin{array}{l}0.000 \\
0.720\end{array}$ \\
\hline $\begin{array}{l}\text { Observations } \\
\text { Number of id }\end{array}$ & $\begin{array}{l}938 \\
72\end{array}$ & $\begin{array}{l}938 \\
72\end{array}$ & $\begin{array}{l}938 \\
72\end{array}$ & $\begin{array}{c}879 \\
69\end{array}$ \\
\hline
\end{tabular}

This table presents dynamic panel data esimates of the determinants of annual spending on the bureaucracy as defined in Section 3. Columns (1) - (4) report A/B estimates using $\tilde{O}_{i t}$ as described in Section 3. Sargan overidentifying test p-values and tests of autocorrelation are reported below regression results. Constants and 2 lags of the dependent variable suppressed for brevity. 4 lags of the dependent variable are included. Two step optimal GMM Standard errors are reported in parentheses *, ** and ${ }^{* * *}$ denote statistical significance at the $10 \%, 5 \%$ and $1 \%$ levels. 


\section{A. Appendix: Proofs and Derivations}

\section{A.1. Proofs of Propositions}

Proof of Lemma 1. For the consumer problem to be interior for all groups $i \in\{r, b, e, w\}$ we require that: (i) for each $i, y^{i}>p(\alpha-p)$ for all $p \in\left[p_{a} \pm v\right]$; (ii) that $q=1$ so that demand for both $x_{c}$ and $x_{f}$ are positive. We will first establish that (i) holds for any given $q$ and then (ii) that given sufficient income equilibrium entails $q=1$.

(i) This is most easily established for $y^{b}$ and $y^{e}$; these are identical in equilibrium so we will take $y^{e}$ as representative. By (2.1), and in autarky using (3.1) to determine $p$, we see that we can always set $H$ sufficiently large to ensure that $y^{e}=p H>p(\alpha-p)$. (In autarky the inequality simplifies to $H>\left(1-\theta^{b}\right) \lambda^{m} H$ which is always satisfied.)

In order to satisfy $y^{w}>p(\alpha-p)$ we require

$$
q \underline{y}>p(\alpha-p)
$$

for all values of $p \in\left[p_{a} \pm v\right]$. The approach will be to first establish that the right hand side of the inequality is strictly concave in $p$. It will then be possible to identify a condition on $\alpha$ for which the condition is satisfied for the value of $p$ at which $p(\alpha-p)$ is maximized, and hence all other values of $p \in\left[p_{a} \pm v\right]$ as well. Since $d(p(\alpha-p)) / d p=\alpha-2 p$ and $d^{2}(p(\alpha-p)) / d p^{2}=-2$, we have that $p(\alpha-p)$ is maximized at $p=\alpha / 2$ and that $p(\alpha-p)=\alpha^{2} / 4$ at its maximum. Therefore we require that $q \underline{y}>\alpha^{2} / 4$, or $2(q \underline{y})^{\frac{1}{2}}>\alpha$. The restriction $\alpha \geq v+\underline{\alpha}=v+\left(1-\theta^{b}\right) \lambda^{m} H$ may thus be satisfied by making $v$ and $\lambda^{m}$ sufficiently small.

By (2.3), $y^{r}$ is increasing in $L$ while $p(\alpha-p)$ does not depend on $L$, so it is possible to make $L$ sufficiently large that $y^{r}>p(\alpha-p)$. The specific details are as follows. Using (2.3), for $L$ sufficiently large,

$$
\begin{aligned}
y^{r}\left(q, y^{b}, \theta^{b}\right) & =L-\left(\left(\lambda^{r} L-\lambda^{r}\right) q \underline{y}+\theta^{b} \lambda^{m} y^{b}\right) / \lambda^{r} \\
& >p(\alpha-p)
\end{aligned}
$$

where we have substituted $\lambda^{r} L$ for $\lambda^{c}$ in (2.3). Bringing $L$ to the left hand side and simplifying, we have

$$
L>\frac{\theta^{b} \lambda^{m} y^{b}+\lambda^{r}(p(\alpha-p)-q \underline{y})}{(1-q \underline{y}) \lambda^{r}}
$$


and since there are no other constraints on the size of $L$, this can be made sufficiently large to ensure that the inequality is satisfied.

(ii) To establish that the market for food clears at $q=1$, assume that $q=1$ and then show that as a result of any perturbation to $q \neq 1$, equilibrium will be restored at $q=1$ and at no other value. In the initial equilibrium, wages in the commodity and food sectors, $w_{c}$ and $w_{f}$, must be equalized so that labor allocates in both sectors; $w_{f}=\underline{y}=w_{c}$. Moreover, by the consumer problem equilibrium must entail $q=1$ so that $x_{c}$ and $x_{f}$ are both positive. Without loss of generality, suppose that $q$ is perturbed to $q<1$. Then we must have $w_{f}=q \underline{y}<w_{c}$. This generates excess supply of labor to the latifundia and so $w_{c}$ falls to $w_{f}=q \underline{y}=w_{c}$, as a result of which allocations of labor across sectors are unchanged and hence outputs are unchanged. However, with $q<1$ all income is directed towards demand for food and away from the commodity, so there is excess demand for food and no demand for the commodity. Consequently, $q$ rises to the point where once again $q=1$. Under free trade, given the assumption that consumers in the rest of the world consume both the commodity and food, economic equilibrium under trade integration must imply $q=1$ as well.

Proof of Proposition 1. It remains only to establish conditions under which $d h\left(\theta^{b}, p_{a}\right) / d \theta^{b}<$ 0 . Differentiating (4.3) with respect to $\theta^{b}$ and simplifying, we obtain

$$
\frac{d h\left(\theta^{b}, p_{a}\right)}{d \theta^{b}}=-\lambda^{m} H\left(\alpha-\left(1-2 \theta^{b}\right) \lambda^{m} H\right)
$$

Observe that, for $\alpha$ sufficiently large, $d h\left(\theta^{b}, p_{a}\right) / d \theta^{b}<0$. Finally, at $\alpha=\underline{\alpha}, d h\left(\theta^{b}, p_{a}\right) / d \theta^{b}=$ $-\theta^{b}\left(\lambda^{m} H\right)^{2}<0$ so for all $\alpha>\underline{\alpha}$ we have that $d h\left(\theta^{b}, p_{a}\right) / d \theta^{b}<0$ as required.

Proof of Proposition 2. The aim is to show that $d \Omega\left(\widetilde{\theta}^{b}(p), p\right) / d p>0$ at the autarky price, $p_{a}$. First, to obtain $\Omega\left(\widetilde{\theta}^{b}(p), p\right)$, use the expression for $\widetilde{\theta}^{b}(p)$ given by $(4.2)$ in the expression for $\Omega\left(\theta^{b}, p\right)$ given by $(2.5)$. Then differentiate the resulting expression with respect to $p$ and simplify to obtain:

$$
\frac{d \Omega\left(\widetilde{\theta}^{b}(p), p\right)}{d p}=p-\alpha+\lambda^{m} H .
$$


Now use (3.1) and (4.2) to obtain an expression for $p_{a}$ as a function of $\widetilde{\theta}^{b}(p)$ :

$$
p_{a}=\frac{1}{2}\left(\alpha-\lambda^{m} H+\frac{\sqrt{\left(\alpha \lambda^{m} H-\left(\lambda^{m} H\right)^{2}\right)+4\left(\lambda^{m} H\right)^{2}\left(\lambda^{r} L-\lambda^{r}(L-1) \underline{y}-d\right)}}{\lambda^{m} H}\right)
$$

Using this to substitute for $p$ in the above, observe that $d \Omega\left(\widetilde{\theta}^{b}(p), p\right) / d p>0$ providing that $\lambda^{r} L-\lambda^{r}(L-1) \underline{y}-d>0$, which is satisfied given $\widetilde{\theta}^{b}(p) \in(0,1)$; see (4.2).

\section{A.2. Derivation of the Surplus from Revolution}

The economic surplus generated by a revolution is determined using a Nash Bargaining Solution (NBS), where the bargain is between the middle classes and the workers. This surplus is determined in the usual way as the difference between the payoff to the lower classes from revolution and the payoff to them from maintaining the status quo. $W$ is the total surplus generated by the lower classes:

$$
W\left(\theta^{b}, y^{r}, y^{b}, y^{e}, y^{w}, p\right) \equiv \lambda^{m}\left(\theta^{b} v^{b}\left(y^{b}, p\right)+\left(1-\theta^{b}\right) v^{e}\left(y^{e}, p\right)\right)+\lambda^{w} v^{w}\left(y^{w}, p\right) .
$$

where the first term on the right hand side measures surplus generated by the middle classes and the second term measures the same for the workers. From this definition, and using (2.1)-(2.2), we can determine a reduced form for the total payoff to the lower classes from maintaining the status quo, $W_{s q}$ :

$$
W_{s q}(p)=\lambda^{m}\left(p H+\frac{1}{2}(\alpha-p)^{2}\right)+\lambda^{w}\left(\underline{y}+\frac{1}{2}(\alpha-p)^{2}\right),
$$

where the first term measures the welfare of the middle classes and the second term measures that of workers. The total payoff to the lower classes from mounting a revolution, $W_{\text {rev }}$, is determined as follows:

$$
W_{\text {rev }}\left(\theta^{b}, p\right) \equiv \lambda^{r} y^{r}\left(\theta^{b}, p\right)-d+\lambda^{m}\left(p H+\frac{1}{2}(\alpha-p)^{2}\right)+\lambda^{w}\left(\underline{y}+\frac{1}{2}(\alpha-p)^{2}\right) .
$$

Here, the first term measures the gain to the lower classes from revolution in terms of the increase in their income and hence welfare derived through possession of the latifundia net of the cost of revolution. Then the total net surplus for the lower classes generated by revolution is $h\left(\theta^{b}, p\right) \equiv W_{\text {rev }}\left(\theta^{b}, p\right)-W_{s q}(p)=\lambda^{r} y^{r}\left(\theta^{b}, p\right)-d$. Thus we have (4.1). The total surplus received by group $i \in\{m, w\}$, as calculated by the NBS, is then given by $s^{i}=\lambda^{i} v^{i}\left(p, y^{i}\right)+\frac{1}{2}\left(\lambda^{r} y^{r}\left(\theta^{b}, p\right)-d\right)$. 


\section{A.3. Derivation of Estimating Equation}

To develop the empirical model, we introduce additional flexibility by allowing for observed persistence in the dependent variable and the possibility of other confounders, which we will denote by $\mathbf{Z}$. We now introduce the following general functions for $A_{i t}$ and $B_{i t}$, which represent $A$ and $B$ in country $i$ and period $t$ respectively: ${ }^{37}$

$$
\begin{gathered}
A_{i t}=A_{i t}\left(\sum_{t=0}^{\tau} D_{i, t-1}, p\left(O_{i t}\right), \mathbf{Z}_{i t}\right) \\
B_{i t}=B_{i t}\left(p\left(O_{i t}\right), \mathbf{Z}_{i t}\right) .
\end{gathered}
$$

where $\mathbf{Z}_{i t}$ is a vector of time-varying country-specific confounders. These functions replace the functions $A(p)$ and $B(p)$ introduced earlier, allowing us to condition on unobservable covariates and persistence in the dependent variable. We may then write

$$
D_{i t}\left(\sum_{t=0}^{\tau} D_{i, t-1}, p\left(O_{i t}\right), \mathbf{Z}_{i t}\right)=A_{i t}\left(\sum_{t=0}^{\tau} D_{i, t-1}, p\left(O_{i t}\right), \mathbf{Z}_{i t}\right)+B_{i t}\left(p\left(O_{i t}\right), \mathbf{Z}_{i t}\right)
$$

To obtain an estimating equation, we linearly approximate $D_{i t}\left(\sum_{t=0}^{\tau} D_{i, t-1}, p\left(O_{i t}\right), \mathbf{Z}_{i t}\right)$ under monotonicity of $p(\cdot)$ and additive separability of $A(\cdot)$ and $B(\cdot)$ :

$$
\begin{gathered}
A_{i t}=\sum_{t=0}^{\tau} a_{t} D_{i, t-1}+b O_{i t}+\mathbf{c} \mathbf{Z}_{i t}+\varepsilon_{i t}^{a} \\
B_{i t}=d O_{i, t}+\mathbf{e} \mathbf{Z}_{i t}+\varepsilon_{i t}^{d}
\end{gathered}
$$

where $a_{t}, b, d$ are scalar parameters, $\mathbf{c}$ and $\mathbf{e}$ are parameter vectors and $\varepsilon_{i t}^{a}, \varepsilon_{i t}^{d}$ are idiosyncratic errors. Using equation (A.1) and collecting terms we can then write

$$
D_{i t}=\sum_{t=0}^{\tau} a_{t} D_{i, t-1}+(b+d) O_{i t}+(\mathbf{c}+\mathbf{e}) \mathbf{Z}_{i t}+\varepsilon_{i t}
$$

where $\varepsilon_{i t}=\varepsilon_{i t}^{a}+\varepsilon_{i t}^{d}$. This expression is then differenced and the interactive dummy $C_{i}$ is introduced to obtain (5.5).

\footnotetext{
${ }^{37}$ Allowing $B_{i t}$ to depend on previous values of total government employment, $\sum_{t=0}^{\tau} D_{i, t-1}$, would complicate the interpretation of coefficients by introducing incomplete adjustment of the pampered bureaucracy within a period to changes in trade integration.
} 


\section{B. Appendix: Tables}

Table A1. List of Countries

\begin{tabular}{llll}
\hline Albania & Dominica & Lesotho & Rwanda \\
Australia & Dominican Rep & Liberia & Senegal \\
Austria & Egypt & Lithuania & Seychelles \\
Azerbaijan & El Salvador & Luxembourg & Singapore \\
Barbados & Estonia & Madagascar & Slovak Rep \\
Belarus & Finland & Malaysia & Slovenia \\
Belgium & France & Maldives & South Africa \\
Benin & Gabon & Mali & Spain \\
Bhutan & Georgia & Malta & Sri Lanka \\
Bolivia & Germany & Mauritius & Sweden \\
Brazil & Greece & Mexico & Switzerland \\
Bulgaria & Guinea & Moldova & Tajikistan \\
Burundi & Haiti & Mongolia & Tanzania \\
Costa Rica & Honduras & Morocco & Thailand \\
Croatia & Hungary & Netherlands & Togo \\
Cyprus & Iceland & Nicaragua & Tunisia \\
Czech Rep & India & Niger & Turkey \\
Denmark & Indonesia & Norway & Ukraine \\
Congo, Rep & Ireland & Pakistan & UAE \\
Comoros & Israel & Paraguay & United Kingdom \\
Colombia & Italy & Peru & United States \\
Chile & Jamaica & Poland & Uruguay \\
Chad & Kazakhstan & Portugal & Vanuatu \\
Cameroon & Latvia & Romania & Zambia \\
Djibouti & Lebanon & Russia & Zimbabwe \\
\hline
\end{tabular}

Notes: This table provides a list of countries for which there exist data on bureaucracy size, GDP, government revenue, IMF loans, population, c.a. and trade integration. The unbalanced panel spans the years 1972-2008. 


\begin{tabular}{|c|c|c|c|c|c|}
\hline & $\begin{array}{c}(1) \\
\mathrm{B} / \mathrm{B}\end{array}$ & $\begin{array}{c}(2) \\
\mathrm{B} / \mathrm{B}\end{array}$ & $\begin{array}{c}(3) \\
\mathrm{B} / \mathrm{B}\end{array}$ & $\begin{array}{c}(4) \\
\mathrm{B} / \mathrm{B}\end{array}$ & $\begin{array}{c}(5) \\
\mathrm{B} / \mathrm{B}\end{array}$ \\
\hline Trade integration $(\mathrm{t}) \times$ primary & $\begin{array}{c}0.195^{* * *} \\
(0.005)\end{array}$ & $\begin{array}{c}0.155^{* * *} \\
(0.024)\end{array}$ & $\begin{array}{c}0.195^{* * *} \\
(0.014)\end{array}$ & $\begin{array}{l}0.227^{* * *} \\
(0.008)\end{array}$ & $\begin{array}{c}0.160^{* * *} \\
(0.024)\end{array}$ \\
\hline Trade integration $(\mathrm{t})$ & $\begin{array}{l}0.013^{*} \\
(0.007)\end{array}$ & $\begin{array}{c}0.018 \\
(0.034)\end{array}$ & $\begin{array}{c}-0.975^{* * *} \\
(0.047)\end{array}$ & $\begin{array}{l}-0.618^{* * *} \\
(0.046)\end{array}$ & $\begin{array}{c}-0.875^{* * *} \\
(0.072)\end{array}$ \\
\hline Population (t) & & $\begin{array}{c}-0.014^{* *} \\
(0.006)\end{array}$ & $\begin{array}{c}0.017^{* * *} \\
(0.005)\end{array}$ & $\begin{array}{l}0.137^{* * *} \\
(0.005)\end{array}$ & $\begin{array}{l}-0.020 \\
(0.013)\end{array}$ \\
\hline Government revenue $(\mathrm{t})$ & & $\begin{array}{c}-4.45 \mathrm{e}-07^{* * *} \\
(3.27 \mathrm{e}-08)\end{array}$ & & & $\begin{array}{c}-1.88 \mathrm{e}-07^{* * *} \\
(4.00 \mathrm{e}-08)\end{array}$ \\
\hline $\operatorname{GDP}(\mathrm{t})$ & & & $\begin{array}{c}0.594^{* * *} \\
(0.007)\end{array}$ & & $\begin{array}{c}0.547^{* * *} \\
(0.028)\end{array}$ \\
\hline Per-capita income (t) & & & & $\begin{array}{l}0.483^{* * *} \\
(0.025)\end{array}$ & $\begin{array}{l}-0.053 \\
(0.042)\end{array}$ \\
\hline $\begin{array}{l}\text { Sargan Test (p-value) } \\
\text { Serial correlation: }\end{array}$ & 1.00 & 1.00 & 1.00 & 1.00 & 1.00 \\
\hline $\begin{array}{l}\text { 1st order (p-value }) \\
\text { 2nd order ( } p \text {-value })\end{array}$ & $\begin{array}{l}0.001 \\
0.214\end{array}$ & $\begin{array}{l}0.000 \\
0.072\end{array}$ & $\begin{array}{l}0.000 \\
0.392\end{array}$ & $\begin{array}{l}0.001 \\
0.400\end{array}$ & $\begin{array}{l}0.000 \\
0.119\end{array}$ \\
\hline $\begin{array}{l}\text { Observations } \\
\text { Number of id }\end{array}$ & $\begin{array}{l}1471 \\
98\end{array}$ & $\begin{array}{l}1376 \\
94\end{array}$ & $\begin{array}{l}1471 \\
98\end{array}$ & $\begin{array}{l}1471 \\
98\end{array}$ & $\begin{array}{c}1376 \\
94\end{array}$ \\
\hline
\end{tabular}

This table presents dynamic panel data estimates of the determinants of annual spending on the bureaucracy. Columns (1) - (4) report estimates from B/B using. $\tilde{O}_{i t}$ described in Section 3. Sargan overidentifying test p-values and tests of 2 nd order autocorrelation are reported below regression results. Constants and lags of the dependent variable suppressed. 2 lags of the dependent variable are included. Two step optimal GMM Standard errors in parentheses *, ** and *** denote statistical significance at the $10 \%, 5 \%$ and $1 \%$ levels. 
Appendix Table A3. Blundell-Bond estimator Countries Differentiated by Level of Development

\begin{tabular}{|c|c|c|c|c|c|}
\hline & $\begin{array}{c}(1) \\
\mathrm{B} / \mathrm{B}\end{array}$ & $\begin{array}{c}(2) \\
\mathrm{B} / \mathrm{B}\end{array}$ & $\begin{array}{c}(3) \\
\mathrm{B} / \mathrm{B}\end{array}$ & $\begin{array}{c}(4) \\
\mathrm{B} / \mathrm{B}\end{array}$ & $\begin{array}{c}(5) \\
\mathrm{B} / \mathrm{B}\end{array}$ \\
\hline $\begin{array}{l}\text { Trade integration }(\mathrm{t}) \times \text { primary } \\
\times \text { developing }\end{array}$ & $\begin{array}{c}0.258^{* * *} \\
(0.044)\end{array}$ & $\begin{array}{c}0.159^{* * *} \\
(0.036)\end{array}$ & $\begin{array}{c}0.245^{* * *} \\
(0.034)\end{array}$ & $\begin{array}{c}0.227^{* * *} \\
(0.039)\end{array}$ & $\begin{array}{c}0.163^{* * *} \\
(0.039)\end{array}$ \\
\hline $\begin{array}{l}\text { Trade integration }(\mathrm{t}) \times \text { primary } \\
\times \text { developed }\end{array}$ & $\begin{array}{c}0.126^{* * *} \\
(0.034)\end{array}$ & $\begin{array}{l}0.095^{*} \\
(0.049)\end{array}$ & $\begin{array}{l}-0.061 \\
(0.046)\end{array}$ & $\begin{array}{l}-0.019 \\
(0.034)\end{array}$ & $\begin{array}{l}-0.015 \\
(0.037)\end{array}$ \\
\hline Trade integration $(\mathrm{t}) \times$ developing & $\begin{array}{c}0.201^{* * *} \\
(0.048)\end{array}$ & $\begin{array}{c}0.422^{* * *} \\
(0.120)\end{array}$ & $\begin{array}{l}-0.086 \\
(0.073)\end{array}$ & $\begin{array}{c}0.213^{* * *} \\
(0.060)\end{array}$ & $\begin{array}{l}-0.018 \\
(0.113)\end{array}$ \\
\hline Trade integration $(\mathrm{t}) \times$ developed & $\begin{array}{c}0.088^{* * *} \\
(0.020)\end{array}$ & $\begin{array}{c}0.173^{* *} \\
(0.075)\end{array}$ & $\begin{array}{c}-0.858 * * * \\
(0.055)\end{array}$ & $\begin{array}{c}-0.457^{* * *} \\
(0.045)\end{array}$ & $\begin{array}{l}-0.731^{* * *} \\
(0.092)\end{array}$ \\
\hline Population (t) & & $\begin{array}{l}-0.019 * \\
(0.008)\end{array}$ & $\begin{array}{l}-0.015 \\
(0.012)\end{array}$ & $\begin{array}{c}0.158^{* * *} \\
(0.012)\end{array}$ & $\begin{array}{c}-0.047^{* * *} \\
(0.016)\end{array}$ \\
\hline Government revenue $(\mathrm{t})$ & & $\begin{array}{c}-4.71 \mathrm{e}-07^{* * *} \\
(1.03 \mathrm{e}-07)\end{array}$ & & & $\begin{array}{c}0.569^{* * *} \\
(0.021)\end{array}$ \\
\hline GDP $(t)$ & & & $\begin{array}{c}0.631^{* * *} \\
(0.010)\end{array}$ & & $\begin{array}{c}-2.15 \mathrm{e}-07^{* * *} \\
(2.86 \mathrm{e}-08)\end{array}$ \\
\hline Per-capita income (t) & & & & $\begin{array}{c}0.548^{* * *} \\
(0.016)\end{array}$ & $\begin{array}{l}-0.033 \\
(0.035)\end{array}$ \\
\hline Sargan Test (p-value) & 1.00 & 1.00 & 1.00 & 1.00 & 1.00 \\
\hline $\begin{array}{l}\text { Serial correlation: } \\
\text { 1st order ( } p \text {-value) } \\
\text { 2nd order ( } p \text {-value) }\end{array}$ & $\begin{array}{l}0.0006 \\
0.196\end{array}$ & $\begin{array}{l}0.000 \\
0.206\end{array}$ & $\begin{array}{l}0.0001 \\
0.426\end{array}$ & $\begin{array}{l}0.0007 \\
0.400\end{array}$ & $\begin{array}{l}0.000 \\
0.097\end{array}$ \\
\hline $\begin{array}{l}\text { Observations } \\
\text { Number of id }\end{array}$ & $\begin{array}{l}1471 \\
98\end{array}$ & $\begin{array}{l}1257 \\
89\end{array}$ & $\begin{array}{l}1471 \\
98\end{array}$ & $\begin{array}{l}1471 \\
98\end{array}$ & $\begin{array}{c}1376 \\
94\end{array}$ \\
\hline
\end{tabular}

This table presents dynamic panel data esimates of the determinants of annual spending on the bureaucracy. Column (1) - (4) report estimates from B/B using. $\tilde{O}_{i t}$ described in section 3. Sargan overidentifying test p-values and tests of 2 nd order autocorrelation are reported below regression results. Constants and lags of the dependent variable suppressed. 2 lags of the dependent variable are included. Two step optimal GMM Standard errors in parentheses *,** and *** denote statistical significance at the $10 \%, 5 \%$ and $1 \%$ levels. 


\begin{tabular}{|c|c|c|c|c|c|}
\hline & $\begin{array}{c}(1) \\
\mathrm{A} / \mathrm{B}\end{array}$ & $\begin{array}{c}(2) \\
\mathrm{A} / \mathrm{B}\end{array}$ & $\begin{array}{c}(3) \\
\mathrm{A} / \mathrm{B}\end{array}$ & $\begin{array}{c}(4) \\
\mathrm{A} / \mathrm{B}\end{array}$ & $\begin{array}{c}(5) \\
\mathrm{A} / \mathrm{B}\end{array}$ \\
\hline Trade integration $(\mathrm{t}) \times$ primary & $\begin{array}{c}0.055^{* * *} \\
(0.005)\end{array}$ & $\begin{array}{c}0.082^{* * *} \\
(0.007)\end{array}$ & $\begin{array}{c}0.111^{* * *} \\
(0.005)\end{array}$ & $\begin{array}{l}0.066^{* * *} \\
(0.008)\end{array}$ & $\begin{array}{c}0.134^{* * *} \\
(0.006)\end{array}$ \\
\hline Trade integration (t) & $\begin{array}{c}-0.060^{* *} \\
(0.023)\end{array}$ & $\begin{array}{l}-0.039 \\
(0.050)\end{array}$ & $\begin{array}{c}-0.124^{* * *} \\
(0.020)\end{array}$ & $\begin{array}{l}-0.440^{* * *} \\
(0.022)\end{array}$ & $\begin{array}{c}-0.113^{* * *} \\
(0.037)\end{array}$ \\
\hline Population (t) & & $\begin{array}{c}0.586^{* * *} \\
(0.073)\end{array}$ & $\begin{array}{c}0.554^{* * *} \\
(0.037)\end{array}$ & $\begin{array}{l}0.746^{* * *} \\
(0.057)\end{array}$ & $\begin{array}{c}0.521^{* * *} \\
(0.058)\end{array}$ \\
\hline Government revenue $(\mathrm{t})$ & & $\begin{array}{c}-3.92 \mathrm{e}-07^{* * *} \\
(4.60 \mathrm{e}-08)\end{array}$ & & & $\begin{array}{c}-3.99 \mathrm{e}-07 * * * \\
(1.04 \mathrm{e}-07)\end{array}$ \\
\hline $\operatorname{GDP}(\mathrm{t})$ & & & $\begin{array}{c}0.771^{* * *} \\
(0.004)\end{array}$ & & $\begin{array}{c}0.747^{* * * *} \\
(0.015)\end{array}$ \\
\hline Per-capita income (t) & & & & $\begin{array}{l}1.135^{* * *} \\
(0.029)\end{array}$ & $\begin{array}{c}-0.194^{* * *} \\
(0.033)\end{array}$ \\
\hline $\begin{array}{l}\text { Sargan Test (p-value) } \\
\text { Serial correlation: }\end{array}$ & 1.000 & 1.000 & 1.000 & 1.000 & 1.000 \\
\hline $\begin{array}{l}\text { 1st order (p-value) } \\
\text { 2nd order (p-value) }\end{array}$ & $\begin{array}{l}0.000 \\
0.397\end{array}$ & $\begin{array}{l}0.000 \\
0.208\end{array}$ & $\begin{array}{l}0.148 \\
0.469\end{array}$ & $\begin{array}{l}0.001 \\
0.892\end{array}$ & $\begin{array}{l}0.000 \\
0.348\end{array}$ \\
\hline $\begin{array}{l}\text { Observations } \\
\text { Number of id }\end{array}$ & $\begin{array}{l}1495 \\
102\end{array}$ & $\begin{array}{l}1344 \\
94\end{array}$ & $\begin{array}{l}1495 \\
102\end{array}$ & $\begin{array}{l}1495 \\
102\end{array}$ & $\begin{array}{c}1344 \\
94\end{array}$ \\
\hline
\end{tabular}

This table presents dynamic panel data esimates of the determinants of annual spending on the bureaucracy. Columns (1) - (4) report estimates from A/B using. $O_{i t}$ described in Section 3. Sargan overidentifying test p-values and tests of 2nd order autocorrelation are reported below regression results. Constants and lags of the dependent variable suppressed. 2 lags of the dependent variable are included. Two step optimal GMM Standard errors in parentheses *,** and *** denote statistical significance at the $10 \%, 5 \%$ and $1 \%$ levels. 
Appendix Table A5. Conventional Openness Measure

Countries Differentiated by Level of Development

\begin{tabular}{|c|c|c|c|c|c|}
\hline & $\begin{array}{c}(1) \\
\mathrm{A} / \mathrm{B}\end{array}$ & $\begin{array}{c}(2) \\
\mathrm{A} / \mathrm{B}\end{array}$ & $\begin{array}{c}(3) \\
\mathrm{A} / \mathrm{B}\end{array}$ & $\begin{array}{c}(4) \\
\mathrm{A} / \mathrm{B}\end{array}$ & $\begin{array}{c}(5) \\
\mathrm{A} / \mathrm{B}\end{array}$ \\
\hline $\begin{array}{l}\text { Trade integration }(\mathrm{t}) \times \text { primary } \\
\times \text { developing }\end{array}$ & $\begin{array}{c}0.067^{* * *} \\
(0.007)\end{array}$ & $\begin{array}{c}0.063^{* * *} \\
(0.011)\end{array}$ & $\begin{array}{c}0.113^{* * *} \\
(0.008)\end{array}$ & $\begin{array}{c}0.052^{* * *} \\
(0.012)\end{array}$ & $\begin{array}{c}0.155^{* * *} \\
(0.010)\end{array}$ \\
\hline $\begin{array}{l}\text { Trade integration }(\mathrm{t}) \times \text { primary } \\
\times \text { developed }\end{array}$ & $\begin{array}{l}-0.007 \\
(0.067)\end{array}$ & $\begin{array}{c}0.048 \\
(0.052)\end{array}$ & $\begin{array}{c}0.075^{* * *} \\
(0.009)\end{array}$ & $\begin{array}{c}0.105^{* * *} \\
(0.011)\end{array}$ & $\begin{array}{l}0.079^{*} \\
(0.047)\end{array}$ \\
\hline Trade integration $(\mathrm{t}) \times$ developing & $\begin{array}{c}-0.129 * * * \\
(0.021)\end{array}$ & $\begin{array}{c}0.064 \\
(0.077)\end{array}$ & $\begin{array}{l}-0.006 \\
(0.057)\end{array}$ & $\begin{array}{c}-0.358^{* * *} \\
(0.032)\end{array}$ & $\begin{array}{c}0.007 \\
(0.070)\end{array}$ \\
\hline Trade integration $(\mathrm{t}) \times$ developed & $\begin{array}{c}0.240^{* * *} \\
(0.069)\end{array}$ & $\begin{array}{c}-0.312^{* * *} \\
(0.053)\end{array}$ & $\begin{array}{c}-0.523^{* * *} \\
(0.079)\end{array}$ & $\begin{array}{c}-0.607 * * * \\
(0.054)\end{array}$ & $\begin{array}{c}-0.564^{* * *} \\
(0.070)\end{array}$ \\
\hline Population (t) & & $\begin{array}{c}0.511^{* * *} \\
(0.073)\end{array}$ & $\begin{array}{c}0.480^{* * *} \\
(0.038)\end{array}$ & $\begin{array}{c}0.727^{* * *} \\
(0.027)\end{array}$ & $\begin{array}{c}0.455^{* * *} \\
(0.070)\end{array}$ \\
\hline Government revenue $(\mathrm{t})$ & & $\begin{array}{c}-3.44 \mathrm{e}-07^{* * *} \\
(4.08 \mathrm{e}-08)\end{array}$ & & & $\begin{array}{c}-4.56 \mathrm{e}-07^{* * *} \\
(9.07 \mathrm{e}-08)\end{array}$ \\
\hline GDP $(t)$ & & & $\begin{array}{c}0.776^{* * *} \\
(0.004)\end{array}$ & & $\begin{array}{c}0.769^{* * *} \\
(0.032)\end{array}$ \\
\hline Per-capita income (t) & & & & $\begin{array}{c}1.107^{* * *} \\
(0.024)\end{array}$ & $\begin{array}{c}-0.220 * * * \\
(0.061)\end{array}$ \\
\hline $\begin{array}{l}\text { Sargan Test (p-value) } \\
\text { Serial correlation: }\end{array}$ & 1.000 & 1.000 & 1.000 & 1.000 & 1.000 \\
\hline $\begin{array}{l}\text { 1st order (p-value) } \\
\text { 2nd order (p-value) }\end{array}$ & $\begin{array}{l}0.000 \\
0.356\end{array}$ & $\begin{array}{l}0.000 \\
0.218\end{array}$ & $\begin{array}{l}0.012 \\
0.428\end{array}$ & $\begin{array}{l}0.000 \\
0.933\end{array}$ & $\begin{array}{l}0.000 \\
0.398\end{array}$ \\
\hline $\begin{array}{l}\text { Observations } \\
\text { Number of id }\end{array}$ & $\begin{array}{l}1471 \\
101\end{array}$ & $\begin{array}{l}1320 \\
93\end{array}$ & $\begin{array}{c}1471 \\
101\end{array}$ & $\begin{array}{l}1471 \\
101\end{array}$ & $\begin{array}{c}1320 \\
93\end{array}$ \\
\hline
\end{tabular}

This table presents dynamic panel data estimates of the determinants of annual spending on the bureaucracy. Columns (1) - (4) report estimates from A/B using $O_{i t}$ described in Section 3. Sargan overidentifying test p-values and tests of 2 nd order autocorrelation are reported below regression results. Constants and lags of the dependent variable suppressed. 2 lags of the dependent variable are included. Two step optimal GMM Standard errors in parentheses $* * *$ and $* * *$ denote statistical significance at the $10 \%, 5 \%$ and $1 \%$ levels. 